
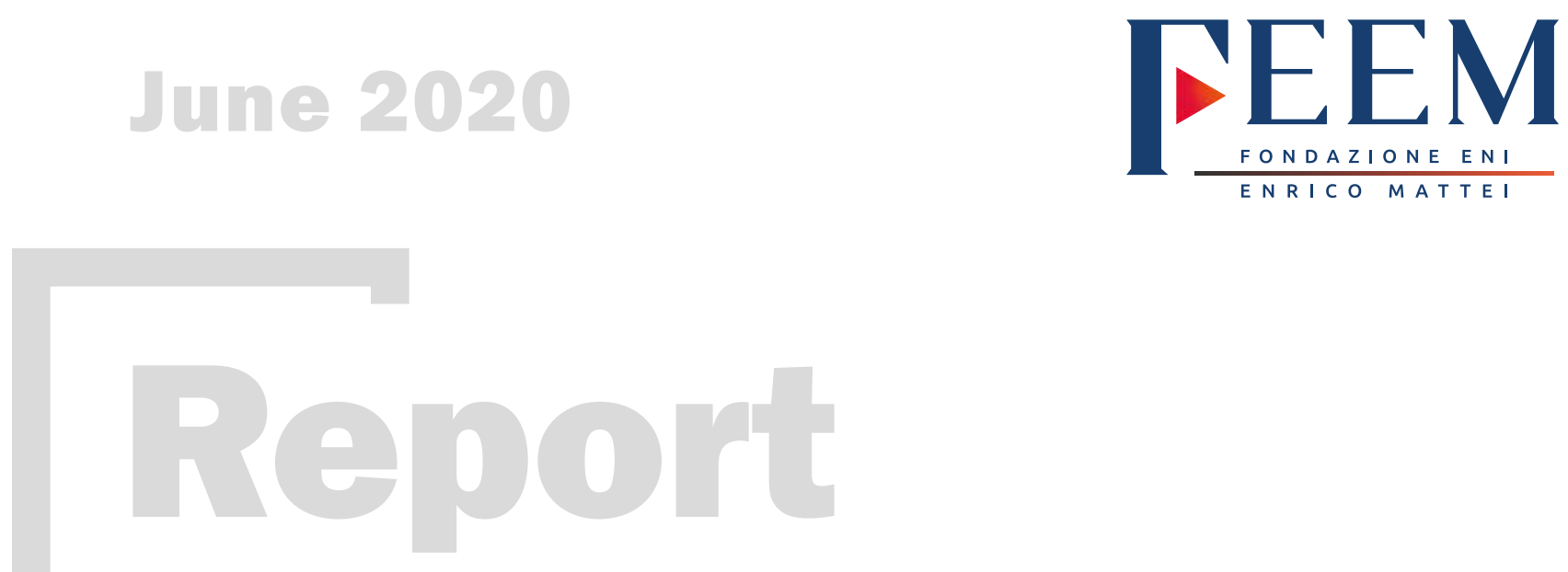

\title{
Supply Chain Analysis with focus on Africa FEEM's Methodological Approach
}

Lamya Adil Suliman Hussain, FEEM

Federica Inzoli, FEEM

Nicolò Golinucci, FEEM

Nicolò Stevanato, FEEM

Matteo Vincenzo Rocco, Department of Energy, Politecnico di Milano

Emanuela Colombo, Department of Energy, Politecnico di Milano 
Supply Chain Analysis with focus on Africa FEEM's Methodological Approach 


\section{Table of contents}

Table of tables

Table of figures

02. Literature review

4.1 Mapping the core processes

4.2 Mapping the actors

4.3 Mapping the specific activities of the actors

4.4 Mapping products flow

4.5 Mapping of technology and knowledge

4.5.1 Technology and Knowledge

4.5.2 Identifying the product standards along the value chain

4.6 Mapping of volumes

4.7 Developing a geographical map of the flow of the products

4.8 Mapping the value at different levels of the value chain

4.9 Mapping the relationships and linkages between the actors

4.10 Mapping the services and governance in the value chain

4.11 Mapping constrains and potential solutions

4.12 Developing a value chain map matrix

05. Process mapping

06. Finding the cause of the problem 


\section{Introduction}

\section{Table of tables}

Table 1 Functional vs Innovative product characteristics 9

Table 2 Further classification of actors 16

Table 3 Eggs flow and transformations in Ghana along the core processes 18

$\begin{array}{lll}\text { Table } 4 & \text { Technologies used by different Millers } & 19\end{array}$

$\begin{array}{lll}\text { Table } 5 & \text { Technology usage according to poultry farm size } & 19\end{array}$

Table 6 Ghana's formal standards for the poultry industry (Source: Ghana 20 Standards Authority)

Table 7 USDA Grade Standard Chart (Source: (United States Department of Agriculture, 2014)

Table 8 Percentage of boiler chicken sales by farms to various channels

Table 9 Cost categories

Table 10 Small scale maize farmers production costs, sales and margins (Source: (M4P, 2008)

Table 11 Chicken supply and production constraints and solutions

Table 12 Poultry value chain map matrix

Supply chain analysis is an expression used to refer to the process of investigating and studying the role and contribution of each economic agent along the supply chain (actors such as producers, traders and consumers, as well as legal entities such as businesses, authorities and development organizations) that contributes directly to the generation of a final product or service. It involves the evaluation of every stage of the supply chain starting from the raw material or intermediate product acquisition and finishes downstream, after several stages of transformation or increase in value and the final delivery of the product to the costumer (Grossi, 2014).

The rise of globalization caused global trading to become more common, increasing the role and importance of supply chain management. Global supply chains usually extend between

Figure 1. Methodology steps industrialized and developing countries, in which the variation of economy, regulations, legalisation and standards pose difficulties in managing the supply chain. Usually developing countries play the role of raw material suppliers or manufacturers to industrialized countries.

However, they face problems affecting the performance of the supply chain, which include instability of governments and policies, corruption, labour intensive industries,

deteriorated infrastructures, limited use of new technologies, underemployment, child labour,

and low education level of the population (Galal \& Moneim, 2016)

This report provides a set of simple and easy to follow tools for analysing supply chains in developing countries. Figure 1 shows the tools that will be utilized in this report to support the analysis.

Figure 1 Methodology steps
Figure 2 Lean, Agile and Leagile supply chains (Source: (Johnsen \& Ciccullo, 2019)

Figure 3 Hau Lee supply chain uncertainty framework (L. \& Lee, 2002)

Figure 4 Mapping of core processes in Ghana's poultry supply chain

Figure 5 Poultry core process actors mapping

Figure 6 Local Chicken meat volumes

Figure 7 Internal trade routes for day-old chicks imported through Kotoka International Airport (Source: (Akunzule, 2004))

Figure 8 Types of relationships between actors

Figure 9 Feed mill process map

Figure 10 5-Whys process flowchart (Source: (Seiter, 2018))

Figure 11 Poultry Ishikawa

Figure 12 TOWS matrix (Source: (Mind Tools, 2020)

Figure 13 Poultry SWOT Analysis

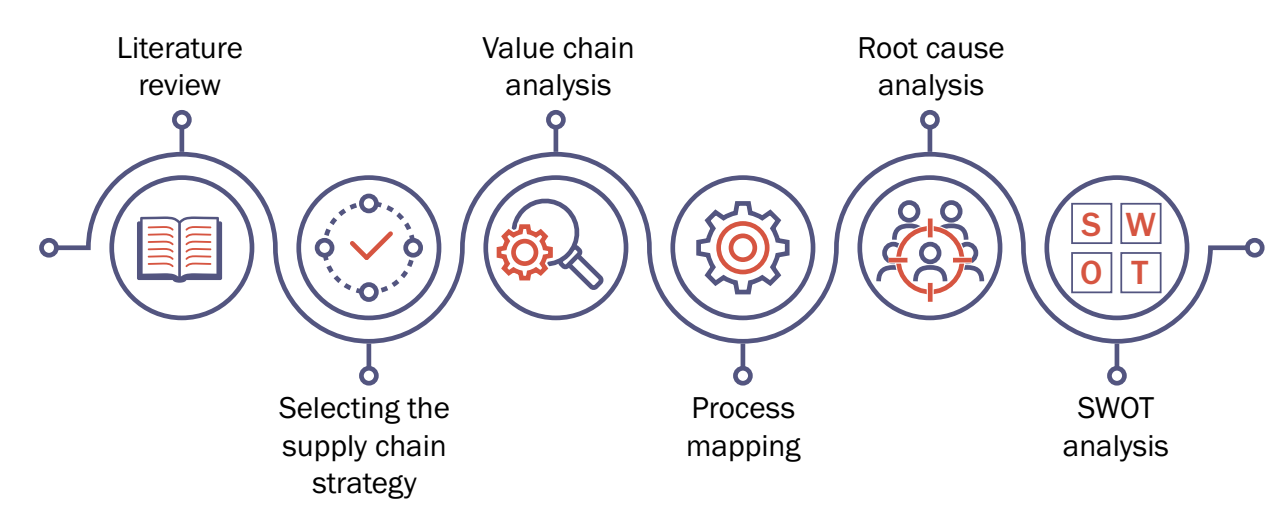


An explanation is provided for each tool, followed by examples of their application, including their real application for the poultry industry in Ghana, for simplification. This methodology can be used by field practitioners those involved in project development and/ or assessment of development opportunities. By following those tools one is capable of obtaining an overall understanding of the supply chain of the selected product/s, as well as identification of the bottlenecks and development of improvement strategies to facilitate the access of the selected product/s and most vulnerable actors to remunerative markets. Once the analysis is completed, it is important to determine which of the identified interventions are realistic in the sense that they can be implemented, considering the costs and benefits of their implementation.

Note: the word poultry will be used to refer to chicken in this report, because in Ghana it is considered as synonymous to chicken, which dominates the poultry industry of the country.

\section{Literature review}

$\left(\frac{10}{2}\right.$

When analysing supply chains of products in developing countries, access to information tends not be easy and the market is segmented and inefficient. Thus, it is important to start by conducting a comprehensive literature review during the preparatory stage of the study, to understand the overall value chain and to provide insights regarding the main areas to focus on during the primary research.

The literature review should incorporate information regarding:

- Who are the main actors in the supply chain and what are their roles?

- Producers/Firms that operate in the industry

- Who are the suppliers to the producers and the total quantities supplied in the past years?
- Exports and imports data such as the quantities and destinations

- Means of transport and logistic firms that are available

- Distribution channels and markets in which products are sold

- The various forms in which the product is sold

- Regulatory bodies, quality standards and certifications

- Systems of co-operatives and associations

- Seasonal production and factors that impact and simulate the production process including variations in demand during the year

- What are the main barriers and opportunities that appear in the supply chain? 


\section{Determining the supply chain strategy}

Once an overall understanding of the supply chain is obtained, the following step is to determine the appropriate supply chain strategy. The term supply chain strategy is often confused with supply chain management, where supply chain operations are controlled to reduce costs. However, supply chain strategy is broader as it defines how the supply chain should operate in order to compete and is an iterative process that evaluates the cost benefit trade-offs of operational components. Another purpose of the supply chain strategy is to establish how to work with supply chain partners, including suppliers, distributors and customers. This is because as markets becomes more competitive, it is essentia to reinforce existing relationships and work together (Happek, 2005). The supply chain strategy of a firm is usually driven by the type of product, patterns of demand, custome requirements and any associated risks which may delay delivery by the supply chain. It is necessary to have a supply chain that is suitable for the product/s in order to achieve optimum performance, and this can be determined by using Fisher framework (L. \& Lee, 2002). According to Fisher, the mismatch between products and their supply chains is the root cause of problems plaguing supply chains.

\section{Objectives}

- Understanding the various strategies and which one to select

- Identifying the attributes used to classify a product

- Distinguishing between functional and innovative products

- Determining the operating conditions of the supply chain

- Distinguishing between physically efficient and market-responsive processes

- Distinguishing between stable and unstable supply processes

Fisher's framework matches the supply chain strategies to the right level of demand uncertainties, that is linked to the predictability of the product demand. The first step is to determine whether the product is functional or innovative and this depends on the product life cycle, contribution margin, productivity, average error in forecast, stock out rate, end-ofseason markdown and lead time for made-toorder products. Table 1 distinguishes between functional and innovative products. A functional product has a predictable demand, long life cycle and low variety, while an innovative product has an unpredictable demand, short life cycle and high variety.

Table 1. Functional vs Innovative product characteristics

\begin{tabular}{|l|l|l|}
\hline \multicolumn{1}{l}{} & Functional (Predictable) & Innovative (Unpredictable) \\
\hline Product life cycle & $>2$ years & 3 month - 1 year \\
\hline Contribution Margin & $5-20 \%$ & $20-60 \%$ \\
\hline Productivity & Low & High \\
\hline Forecast error & $10 \%$ & $40-100 \%$ \\
\hline Stock out rate & $1-2 \%$ & $10-40 \%$ \\
\hline End of season markdown & $0 \%$ & $10-25 \%$ \\
\hline Lead time for Make-to- order & 6 month - 1 year & 1 day - 2 day \\
\hline
\end{tabular}

Note: To clear the inventory of existing stock before the launch of new stock, sellers often start selling the existing products at discounted huces. This in end of season markdown (MBA Skool, 2008).

The second step is to determine the operating conditions of the supply chain, which can be physically efficient (in case of functiona products) or market-responsive (in case of innovative products). Physically efficient

processes are defined to supply predictable demand efficiently at the lowest possible cost,

Figure 2 Lean, Agile and Leagile supply chains (Source: (Johnsen \& Ciccullo, 2019))

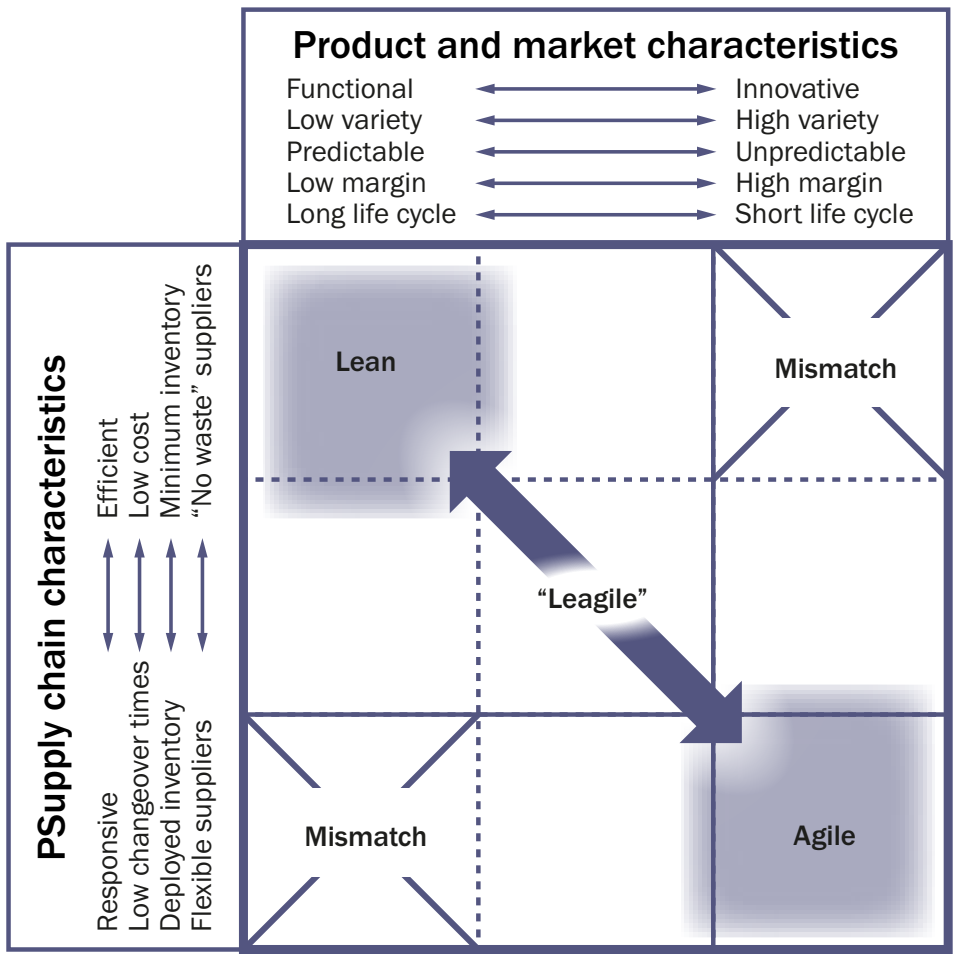
supply chain concepts.

maketresponsive processes respond quickly to unpredictable demand in order to minimize stock-outs, forced markdowns and obsolete inventory. Figure 2 demonstrates Fishers idea while incorporating lean and agile 
A lean supply chain focuses on efficient streamlined operations, that is producing high volumes at a low cost. It focuses on reliability and predictability and its goal is to add value to customers by reducing the cost of goods and lowering waste. In lean supply chains production is planned months or years in advance rather than adapting to a changing market, and this allows to obtain the lowest possible cost for large quantities of goods. On the other hand, agile supply chains are built to be highly flexible in order to quickly adapt to changing situations. Moreover, the supply chain is responsive and can deal with sudden changes with the required speed and flexibility. It is more effective when there is constant stream of new innovative products. By implementing an agile supply chain, organizations can quickly adjust their sourcing, logistics and sales (The Supply Chain Consulting Group, 2020). Typical products that utilize agile supply chains include fashion goods, while for a lean supply chain consumers goods are typical. Leagile supply chain is a hybrid approach which combines both Lean and Agile supply chain concept. At the early stages of a new product, the lean paradigm allows to penetrate the market through low cost production. Then, as the market matures, the agile paradigm begins to replace it as the demand for higher levels of variety grows (Miemczyk, 2014).
When deciding on the appropriate supply chain strategy it is also important to align the supply chain with uncertainties revolving around the supply process. Thus, it is necessary to understand whether the supply process is stable or unstable. A stable supply process is characterized by a mature manufacturing process and technology, and a well-established supply base. Also, it tends to be highly automated and medium/long term contracts are prevalent. Moreover, a stable process is characterized by stable and high yields, reliable sources, greater supply sources, fewer process changes and easiness in effecting changeovers. An unstable supply process is characterized by technology and production processes evolving fast. Its manufacturing process requires a lot of fine tuning and is often subject to breakdown and uncertain yields. In addition, the supply base may not be reliable itself as suppliers maybe going through process innovation (L. \& Lee, 2002). Furthermore, it is characterized by, limited supply sources, and more and difficult process changeovers.

Figure 3 Hau Lee supply chain uncertainty framework(L. \& Lee, 2002)

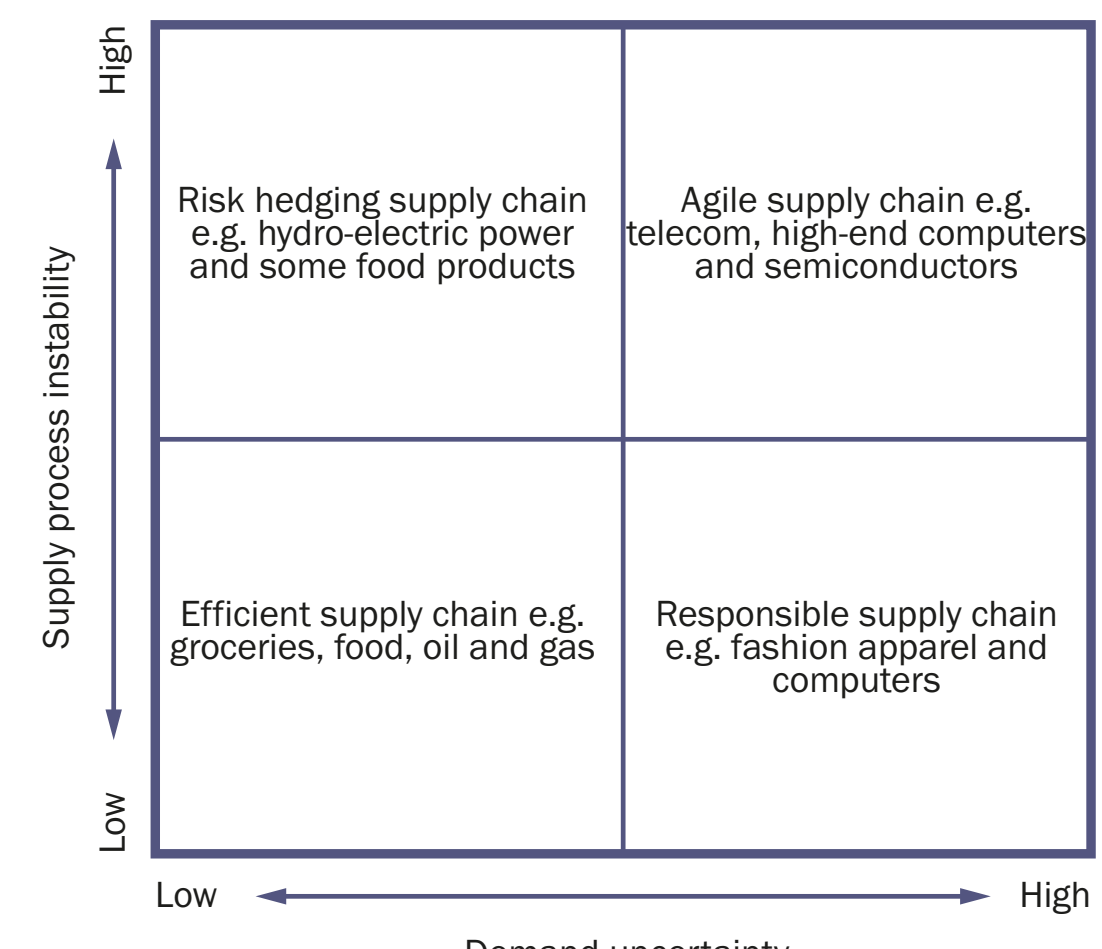

Demand uncertainty

Figure 3 shows the four strategies

recommended, depending on the degree

of the supply process stability and demand uncertainty of the product.

Efficient supply chains - These kind of supply chains utilize strategies aiming to achieve the highest cost efficiencies in the supply chain. To achieve this, non-value adding activities must be eliminated, scale economies and optimization techniques should be applied to achieve the best production capacity utilization. Also, information linkages must be included to ensure the most efficient, accurate and cost-effective transfer of information along the supply chain.

- Risk Hedging supply chains - This kind of supply chains utilize strategies aimed at pooling and sharing resources in the supply chain so as to share the risks in the supply disruption. A company can increase its safety stock to hedge against supply disruption risks and share its safety stock and storage cost with other companies who need these materials as well. This is common in retailing.

- Responsive supply chains - These supply chains utilize strategies aiming to be responsive and flexible to changing and diverse need of customers. In order to be responsive companies, rely on make to order and flexible mass customization processes to meet the specific requirements of the customers. Accurate specification of customer requirements is the key necessity for mass customization.

- Agile supply chain - These supply chains utilize strategies aimed at being responsive and flexible to customer needs while pooling inventory or capacity resources in 
order to hedge risks of supply shortages or disruption. They combine strengths of hedged and responsive supply chains.

Note: Make to order is production approach were products are only produced after the

Example - Determining the supply chain strategy

Based on the literature review it was determined that the appropriate supply chain strategy for poultry in Ghana is the Lean supply chain strategy. Indeed, chicken is a functional product as there are only few varieties. It also has a long product life cycle since the market for chicken is still in maturity phase and is expected to grow as people will continue to consume chicken. Moreover, the profit margins from chicken sales are low and chicken trading requires physically efficient processes that result in minimum inventory and no waste since they are perishable products. In addition, low cost of operation and efficiency are necessary in order to generate profit since the chicken in Ghana is considered to be of higher cost than imported and thus require an efficient supply chain. customer order is received. Mass customization is a manufacturing and marketing technique that combines flexibility and personalization of custom-made products with the low unit costs that are associated with mass production.

\section{Value chain analysis}

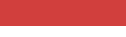

A value chain describes all the activities required to bring a product or service from conception, through the various phases of production (involving a combination of physical transformation and various inputs), delivery to the final consumer and final disposal after use (Kaplinsky \& Morris, 2000). It is an economic system that includes all distribution and supply itineraries used by all producers that aim to sel a similar family of goods which compete on a similar consumer market. On the other hand, a value chain may refer to a certain consumer market e.g. the frozen food chain or it may refer to a specific material market e.g. wheat chain. In the first definition, the itinerary focuses on the product flow from the consumer back to the farmer while the latter is focused on the raw material flow from the farm to the consume (Fourcadet \& Attaie, 2003).

\section{Objectives}

Analysing the value chain of a product wil provide a better understanding of the entire chain from the producer to the consumer, as well as the potential for the selected product in terms of value and market terms. In particula value chain analysis will allow the following:

- Mapping of the actors in the production, distribution, marketing, and sale of the products, to understand the characteristics of the actors, flow of goods along the chains, employment characteristics and final products volumes and regions of sale.
- Obtaining a better understanding of the connections and the interdependencies between the actors and processes.

- Identifying the costs, profits, and margins in the chain to understand how value is distributed along the chain, which actors benefit most and who needs to be supported through improvements.

- Understanding the role of improvements or upgrading in the value chain to allow actors obtain higher values by assessing the profitability of the actors and identifying present limitations and governance issues.

- Understanding the role of both internal and external governance and their impact on the supply chains.

- Identifying investment and development opportunities.

The following sub-sections describe the steps to conduct a value chain analysis combined with some examples. It is important to note that not all steps are compulsory, however they depend on the scope and objectives of the value chain analysis, available resources, and mandate of the organization. Moreover, this is not a linear process i.e. it is not necessary to follow the order of the steps. This is because value chain analysis is not a linear process and should try to capture the dynamics and flexibility within the supply chain. 


\subsection{Mapping the core processes}

The first step is to map the core processes, i.e. the processes the raw material passes through before reaching the final consumption stage, including the provision of inputs to produce the raw materials. In general, a maximum of seven processes that the raw material passes through should be used for simplification. When one or two products are produced from the same raw materials generally, we will have a linear value chain map, as shown in the example. However when more than two products are produced from the same raw materials and each one follows its own processes to the final consumer, then the process map will be more complex. The core processes can be mapped based on the overall understanding of the supply chain obtained from the literature review.

\section{Example - Mapping core processes}

\section{4 maps the core processes of the Ghanaian chicken supply chain. A brief explanation of each process is provided}

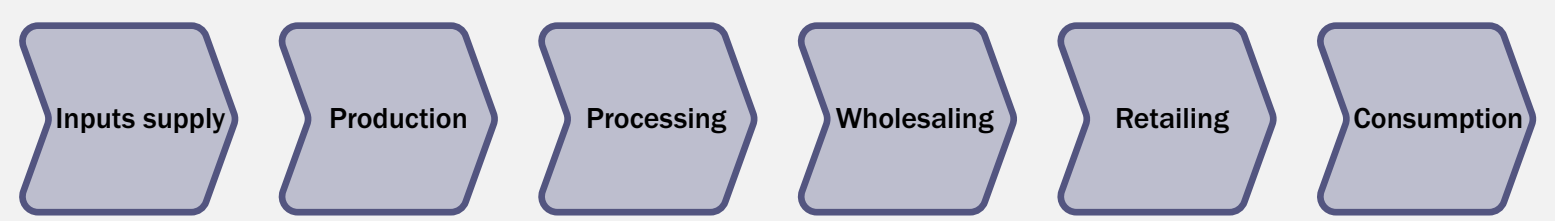

- Inputs supply - Inputs to chicken farms include day-old chicks (DOC), vaccination, drugs, equipment, feed, and feed additives.

- Production - This refers to all activities performed on the farm such as purchasing day-old chicks, raising, feeding, and watering chickens and collecting eggs, etc....

- Processing - It involves the conversion of chickens into meat and the transformation of chicken meat into other products such as frankfurters and sausages.

- Wholesaling - It involves bulk purchasing of eggs, chickens and chicken meat from farms and processing facilities, their transportation and sale to various customers.

- Retailing - It refers to retail activities of purchasing eggs and chickens and chicken meat from wholesalers and their sale to various customers.

Consumption - This includes the various costumers and forms in which the product is consumed.

\subsection{Mapping the actors}

The subsequent step is to determine who are the actors involved in the core processes and what do they do. Distinguishing between the actors depends on the level of sophistication the mapping exercise is trying to reach. Actors can be mapped first by developing a list of the actors in each process, and then distinguishing between the actors according to their occupation after this, they can be further classified for example according to:

- Legal status or type of ownership government, co-operatives, estates or households;
- Size or scale - based on the quantities they produce, land ownership or number of employees;

Location - county, district, province, or country.

An initial list of the actors can be developed

from the literature and then updated through the study, as new actors emerge. Also, if an actor has more than one role along the value chain, it is important to understand which is the main role of the actor, and then to categorise it accordingly.

Example - Mapping of the actors

Figure 5 shows the actors who are involved in the core processes of Ghana's chicken supply chain; actors are categorized according to their occupation.

\section{Figure 5 Poultry core process actors mapping}
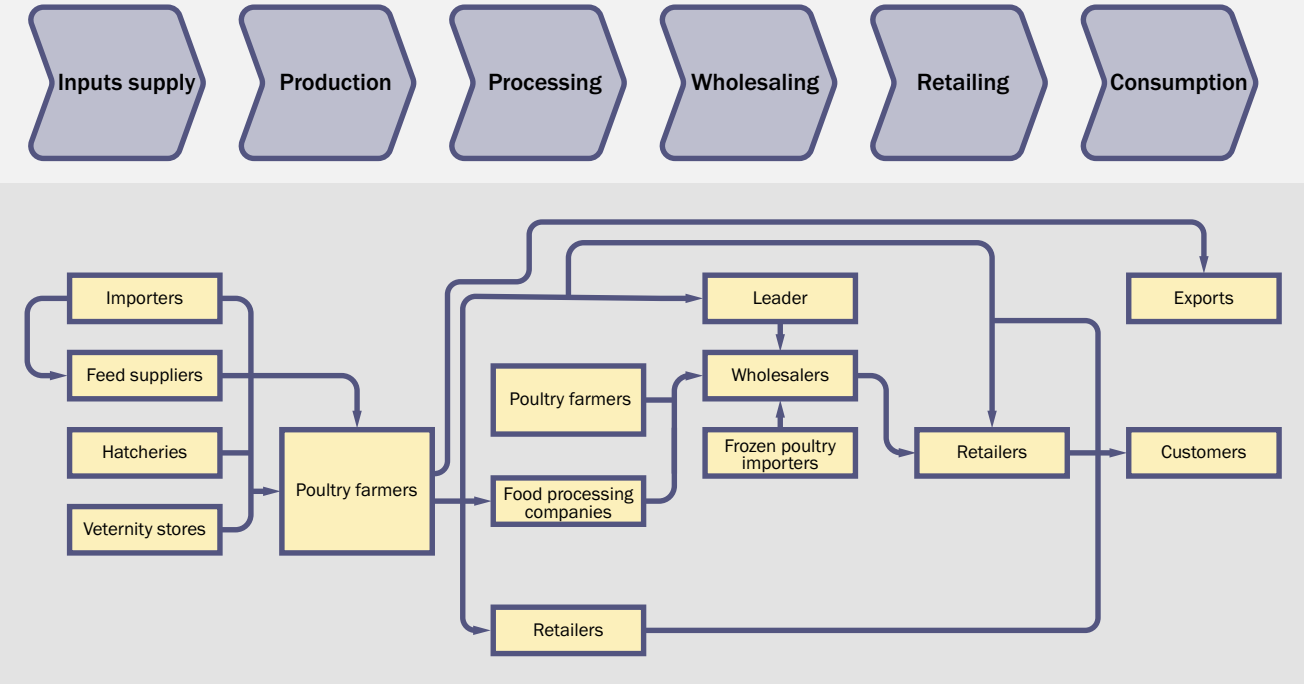

A description of the actors is provided below:

- Inputs suppliers - Importers include suppliers of feed, feed additives, day old chicks and fertile eggs. Feed suppliers include commercial feed mills that produce ready feed for farmers and service mills that produce feed according to the farmer requirements. Hatcheries provide local day-old chicks and veterinary stores provide drugs, feed additives and equipment.

- Farmers - Chicken farmers are classified into three categories: commercial or industrial, semicommercial and backyard producers, depending on their installed capacity, marketing system and level of vertical integration. Another classification for the chicken farmers can be based on the classification of their farms which is based on the above criteria and the level of biosecurity.

- Processors - There are two categories of processors: i) processing of live birds to produce wholedressed broilers or chicken cuts, and ii) processors who convert chicken meat into nugget, sausages, frankfurters, and marinated chicken.

- Wholesalers - They usually operate cold storages and sell imported chicken meat products. Some 
producers also perform wholesaling activities as they sell layer birds to retailers or broiler birds in bulk to caterers or other traders.

- Leader - Purchases live birds and distribute them to wholesalers whom they have an agreement with.

- Retailers - Retailers purchase live birds and resell them, they also provide in situ slaughtering and primary processing (de-feathering and cleaning but not cutting). Also, some retailers purchase frozen chicken from wholesalers and retail them in cold stores or on tables in the market for consumers.

- Consumers -These include households, customers to restaurants, hotels, institutions etc.

- Exporters -These include farmers and other exporters who export eggs and day-old chicks.

\section{Table 2 Further classification of actors}

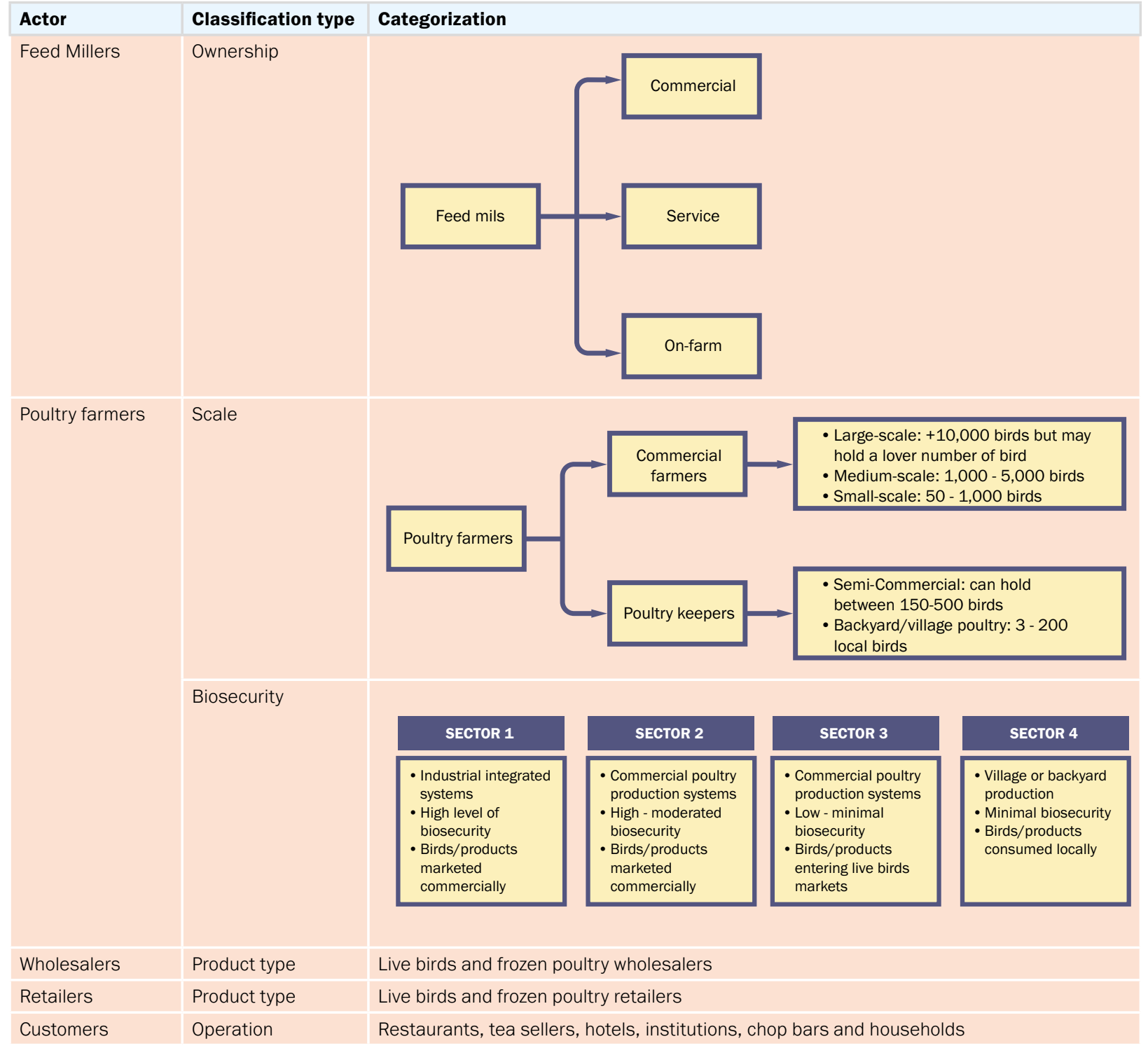

4.3 Mapping the specific activities of the

\section{actors}

The actors map may be further developed

by breaking down the core processes into specific activities performed by the different actors. This will allow to identify overlapping or gaps in activities, potentials for improvement and provide an overall understating of the supply chain. Moreover, there is no limit to the breakdown of the activities, but it rather depends on the researcher's judgement. The breakdown of core processes into activities can be useful when calculating costs and margins since the activity may be viewed as a cost and/ or profit centre for the actor. This step can be captured from the literature review and then confirmed through semi-structured interviews and observation during field visits to capture further details.

Example - Mapping the specific activities of actors

Examples of the specific activities performed by some of the actors are listed below.

Poultry farmers:

- Preparing pens for chickens

- Feeding and watering chickens

- Collecting, sorting, and packing eggs

Processors:

- Slaughtering

- Packing

- Refrigerating

Wholesalers:

- Transporting

- Cold storage

- Selling to costumers/consumer

Retailers:

- Primary processing

- Cold storage

- Selling to consumers

- Collection

- Quality control

- Transporting

Furthermore, it may be useful to also breakdown the activities according to the classification of the actors as this will have an impact on their costs and margins. For instance, it was observed that most of the large-scale commercial farms operate their own feed mills and practice high level bio $\neg$ security. Some even have their own hatchery and parent 
stock, while medium and small categories rely on hatcheries and importers for their day-old chicks and feed mills for feed and practice minimal biosecurity.

\subsection{Mapping products flow}

This step requires identification of the transformation of the products in each stage of the process from input of raw material to intermediate products, and to final products

i.e. the input and output forms of each stage, in order to understand which forms of the product are being handled, transformed and transported at each stage. Particularly, this is useful when it is necessary to understand which stages are needed to reach the final product. This step can be conducted along with the mapping of the activities to understand in which activity the transformation occurs and thus the value addition.

\section{Example - Mapping the product flow}

Table 3 shows the flow and transformations of chicken and eggs in Ghana along the core processes.

\section{Table 3 Eggs flow and transformations in Ghana along the core processes.}

\begin{tabular}{|c|c|c|c|c|c|c|}
\hline Process & Supply inputs & Production & Processing & Wholesaling & Retailing & Consumption \\
\hline Input & & $\begin{array}{l}\text { Day-old chicks, } \\
\text { Feed and } \\
\text { additives, } \\
\text { Vaccination, } \\
\text { Drugs etc... }\end{array}$ & $\begin{array}{l}\text { Live chicken, Egg } \\
\text { crates etc... }\end{array}$ & $\begin{array}{l}\text { Whole dressed } \\
\text { chicken, } \\
\text { Frankfurters, } \\
\text { Sausages, Egg } \\
\text { crates, Live } \\
\text { birds, Pre-cuts, } \\
\text { Eggs crates, } \\
\text { Imported/local } \\
\text { pre-cuts etc... }\end{array}$ & $\begin{array}{l}\text { Live birds, Whole } \\
\text { dressed, chicken, } \\
\text { Imported/ local } \\
\text { pre-cuts etc... }\end{array}$ & $\begin{array}{l}\text { Live birds, } \\
\text { Pre-cuts, } \\
\text { Frankfurters, } \\
\text { Sausages, Eggs, } \\
\text { Boiled eggs, } \\
\text { Imported/local } \\
\text { pre-cuts etc... }\end{array}$ \\
\hline Output & $\begin{array}{l}\text { Day old chicks, } \\
\text { Feed and } \\
\text { additives, } \\
\text { Vaccination, } \\
\text { Drugs etc... }\end{array}$ & $\begin{array}{l}\text { Live chicken, Egg } \\
\text { crates etc.. }\end{array}$ & $\begin{array}{l}\text { Whole dressed } \\
\text { chicken, Pre- } \\
\text { cuts, Sausages, } \\
\text { Nuggets, etc... }\end{array}$ & $\begin{array}{l}\text { Whole dressed } \\
\text { chicken, } \\
\text { Frankfurters, } \\
\text { Sausages, Egg } \\
\text { crates, Live } \\
\text { birds, Pre-cuts, } \\
\text { Eggs crates, } \\
\text { Imported/local } \\
\text { pre-cuts etc... }\end{array}$ & $\begin{array}{l}\text { Live birds, Whole } \\
\text { dressed, chicken, } \\
\text { Imported/ local } \\
\text { pre-cuts etc... }\end{array}$ & \\
\hline
\end{tabular}

\subsection{Mapping of technology and}

\section{knowledge}

The mapping of technology and knowledge should include each process in the value chain. Generally, information flows in both directions between actors; for instance, a trader will provide a farmer with information regarding the product requirements while the farmer will inform the trader about the availability of the product. This should be followed by an analysis of the market channels. For this step both closed and open-ended questionnaires can be used.

\subsubsection{Technology and Knowledge}

First, the different technologies and level of knowledge about them for the various users in the processes should be mapped. When analysing which technology is used in each market channel it is important to analyse from the consumer to the producer to understand customers demand and translate it into the correct technology. Information about the technology and knowledge can be obtained by both observing the types of technologies used and asking questions that allow to obtain information about the knowledge levels and types of technologies being used. For example, by simply asking:

- What are the technologies used to produce the output?

- How they learnt about the technology?

How are the technologies paid for?

What investment in terms of capital, labour and land have been made on these technologies?

- Can the technology be used for other purposes?
Technology includes also means of transportation, tools, packing and labelling methods, treatment, testing and drying methods, etc Mapping of technology is important in order to determine the efficiency and effectiveness of the technologies used Also, to categorise the current and needed technology and analyse their appropriateness in terms of affordability, suitability, accessibility and the available skills and knowledge regarding them. Moreover, to identify the possibilities of upgrading technologies through embedded or external services and collective actions and learning.

\section{Example - Mapping of technology and knowledge}

Table 4 shows the different types of technologies used by different categories of millers and how they learnt about these technologies (kindly note that this information about knowledge is fictitious and must be intended as an example).

\section{Table 4 Technologies used by different Millers

\begin{tabular}{|l|l|l|}
\hline Millers & Knowledge & Technology \\
\hline Commercial Mills & $\begin{array}{l}\text { Knowledge obtained through studies and } \\
\text { training }\end{array}$ & $\begin{array}{l}\text { Fully automated ingredient mixtures \& high } \\
\text { accuracy yelectronic scales }\end{array}$ \\
\hline Service Mills & Knowledge obtained from training & $\begin{array}{l}\text { Manually loaded mixers \& manual scales with } \\
\text { low accuracy }\end{array}$ \\
\hline Owned Mills & $\begin{array}{l}\text { Indigenous knowledge obtained while growing } \\
\text { up or obtained training }\end{array}$ & $\begin{array}{l}\text { Manually loaded mixers \& manual scales with } \\
\text { low accuracy }\end{array}$ \\
\hline
\end{tabular}

\section{Table 5 Technology usage according to poultry farm size}

\begin{tabular}{|l|l|}
\hline Farmer & Technology \\
\hline Small-scale farmers & Use non-automated equipment such as waterers and feeders \\
\hline Medium-scale farmers & Use non-automated equipment but some have automated waterers \\
\hline Large-scale farmers & Highly automated and use automatic waterers and feeders, as well as mechanical feed mixers. \\
\hline
\end{tabular}

4.5.2 Identifying the product standards along the value chain

The different qualities and grades of the product as stated by the actors should be identified and described. Standards can be both formal such as those determined by authorities or informal such as those set by the actors themselves. For formal standards it may be necessary to obtain such information from governmental authorities for some products as they may not all be enforced thus it may occur that some of the actors do not apply some of the standards. 
Example - Identifying product standards

Table 6 shows some of the formal standards that are set for the poultry industry by Ghana Standards

Authority. Depending on the objectives of the study, the researcher should decide on which standards should be looked at in details.

\section{Table 6 Ghana's formal standards for the poultry industry (Source: Ghana Standards Authority)}

\begin{tabular}{|c|c|c|}
\hline Millers & Knowledge & Technology \\
\hline GS-106-1:2018 & $\begin{array}{l}\text { Animal Feeding Stuff - Part } 1 \text { Specification for } \\
\text { Poultry Feed }\end{array}$ & $\begin{array}{l}\text { Specifies the requirements and sampling for } \\
\text { feeds for chicken. Gallus domesticus }\end{array}$ \\
\hline GS-106-2:2018 & $\begin{array}{l}\text { Animal Feeding Stuff } 2 \text { Part - Methods of Test } \\
\text { for Poultry Feeds }\end{array}$ & Specifies the methods of test for Poultry Feeds \\
\hline GS 91: 2015 & $\begin{array}{l}\text { Meat and Meat Products-Specification for } \\
\text { Dressed, Chilled and Frozen Poultry }\end{array}$ & $\begin{array}{l}\text { Gives the requirement and methods of sampling } \\
\text { and for dressed poultry }\end{array}$ \\
\hline GS ISO $936: 2007 \psi$ & $\begin{array}{l}\text { Meat and Meat Products - Determination of } \\
\text { Total Ash }\end{array}$ & $\begin{array}{l}\text { Specifies a method for the determination of } \\
\text { the total ash trom all kinds of meat and meat } \\
\text { products, including poultry }\end{array}$ \\
\hline GS ISO 1841-2: 20074 & $\begin{array}{l}\text { Meat and Meat Products - Determination } \\
\text { of Chloride Content - Part 2: Potentiometric } \\
\text { Method }\end{array}$ & $\begin{array}{l}\text { Specifies a method for the determination of the } \\
\text { chloride contents of meat and meat products. } \\
\text { including poultry, with sodium chloride contents } \\
\text { equal to or greyter than } 0,25 \%(\mathrm{~m} / \mathrm{m})\end{array}$ \\
\hline
\end{tabular}

An example of the quality grading for eggs that is used in USA is shown in table 7, were eggs are graded based on color, shape and dimensions of content.

\section{Table 7 USDA Grade Standard Chart (Source: (United States Department of Agriculture, 2014)}

\begin{tabular}{|c|c|c|c|c|}
\hline Quality Factor & AA Quality & A Quality & B Quality & Inedible \\
\hline Air cell & $\begin{array}{l}1 / 8 \text { inch or less in } \\
\text { depth }\end{array}$ & $\begin{array}{l}3 / 15 \text { inch or less in } \\
\text { depth }\end{array}$ & More than 3/16 inch & Does not apply \\
\hline White & Clear and firm & $\begin{array}{l}\text { Clean, may be } \\
\text { reasonable firm }\end{array}$ & $\begin{array}{l}\text { Clean, may be weak } \\
\text { and watery }\end{array}$ & Does not apply \\
\hline Yolk & Outline slightly defined & $\begin{array}{l}\text { Outline may be fairly } \\
\text { well defined }\end{array}$ & Outline clearly visible & Does not apply \\
\hline Spots (blood or meat) & None & None & $\begin{array}{l}\text { Blood or meat spots } \\
\text { aggregating not more } \\
\text { than } 1 / 8 \text { " in diameter }\end{array}$ & $\begin{array}{l}\text { Blood or meat spots } \\
\text { aggregating more than } \\
1 / 8 \text { " in diameter }\end{array}$ \\
\hline
\end{tabular}

An example of informal standard that have been set by producers in Ghana, is the grading of eggs by farmers according to their size. Farmers classify eggs into small, medium, large, and X-large based on visual observation, because the selling price varies according to the size of the egs.

\subsection{Mapping of volumes}

This requires quantification of the volumes of the products and is closely related to the mapping of the product flow. By mapping the volumes of the product, one can understand the size of the different channels in the supply chain. Volumes can be mapped as a proportion of the total volume of the subsector. The following data should be gathered over a period (months or years) that is to be determined by the researcher:

- Volumes of inputs supplied and demanded for the product

- Production volumes and how are they distributed

- Processed quantities and how are they distributed

- Losses in production, processing, and transportation

- Processors capacities

- Local and international demand and supply

- Import quantities

- Export quantities
- Number of actors and jobs of each type - Forecasts for all the above

Volumes data can be further categorized into volumes by the country, regions, county, provenance, main/dominant producers and processors. For this step, both literature and questionnaires can be used.

\section{Example - Mapping of volumes}

Figure 6 shows an example of one way to map the volumes (kindly note that the values provided are not true but are used for demonstration).

\section{Figure 6 Local Chicken meat volumes}

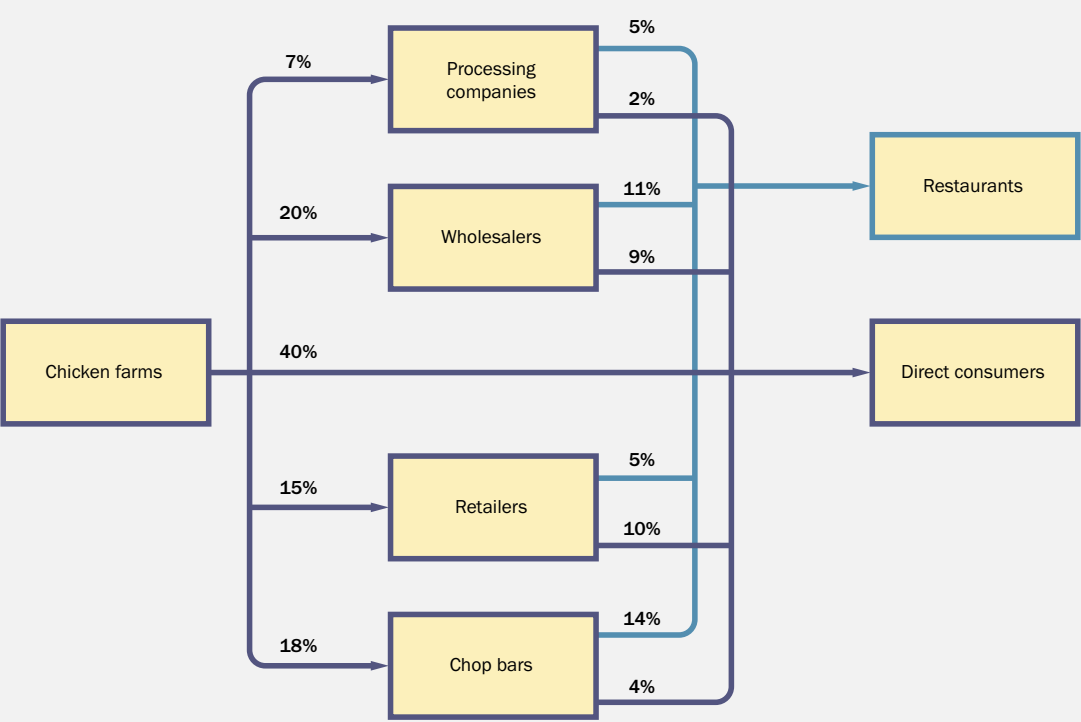

Volumes can be looked at in various ways as each can provide different information. For instance, from Figure 6 one can say that direct sales are most dominant channel. Another way is to also consider imports and exports or to try to understand how much each type of channel is dependent on the various sized chicken farms, as in Table 8 (Vincent Amanor-Boadu, 2016). This will depend on what is of interest to the study being conducted.

Table 8 Percentage of boiler chicken sales by farms to various channels

\begin{tabular}{|l|l|l|l|l|l|l|l|}
\hline Farm size & $\begin{array}{l}\text { Direct-to- } \\
\text { consumers }\end{array}$ & Wholesaler & Retailers & Hawkers & Chop bars & HRI & Processor \\
\hline Small & $57 \%$ & $25 \%$ & $26 \%$ & $39 \%$ & $32 \%$ & $21 \%$ & $2 \%$ \\
\hline Medium & $20 \%$ & $15 \%$ & $17 \%$ & $24 \%$ & $19 \%$ & $25 \%$ & $1 \%$ \\
\hline Large & $24 \%$ & $59 \%$ & $57 \%$ & $38 \%$ & $48 \%$ & $53 \%$ & $97 \%$ \\
\hline
\end{tabular}


4.7 Developing a geographical map of the flow of the products

This step can be done by mapping the actual geographical movement of the products and their various forms on a geographical map of the region from the place of origin up to the final consumer in order to capture a dimension of the product flow (volumes, margins and actors), and understand locational differences. To do this, it is necessary to first identify where each of the processes are physically located, starting from the place of origin, and then trying to go through the wholesalers, retailers and up to the final consumer.

Example - Geographical map of flow of products

Figure 7 shows the trade route for imported day-old chicks through Kotoka International airport, located in Accra. The day-old chicks are distributed to seven live bird markets that are located in the Norther, Brong Ahfao, Volta, Ashanti, Western and Central region.

Figure 7 Internal trade routes for day-old chicks imported through Kotoka International Airport (Source:(Akunzule, 2004))

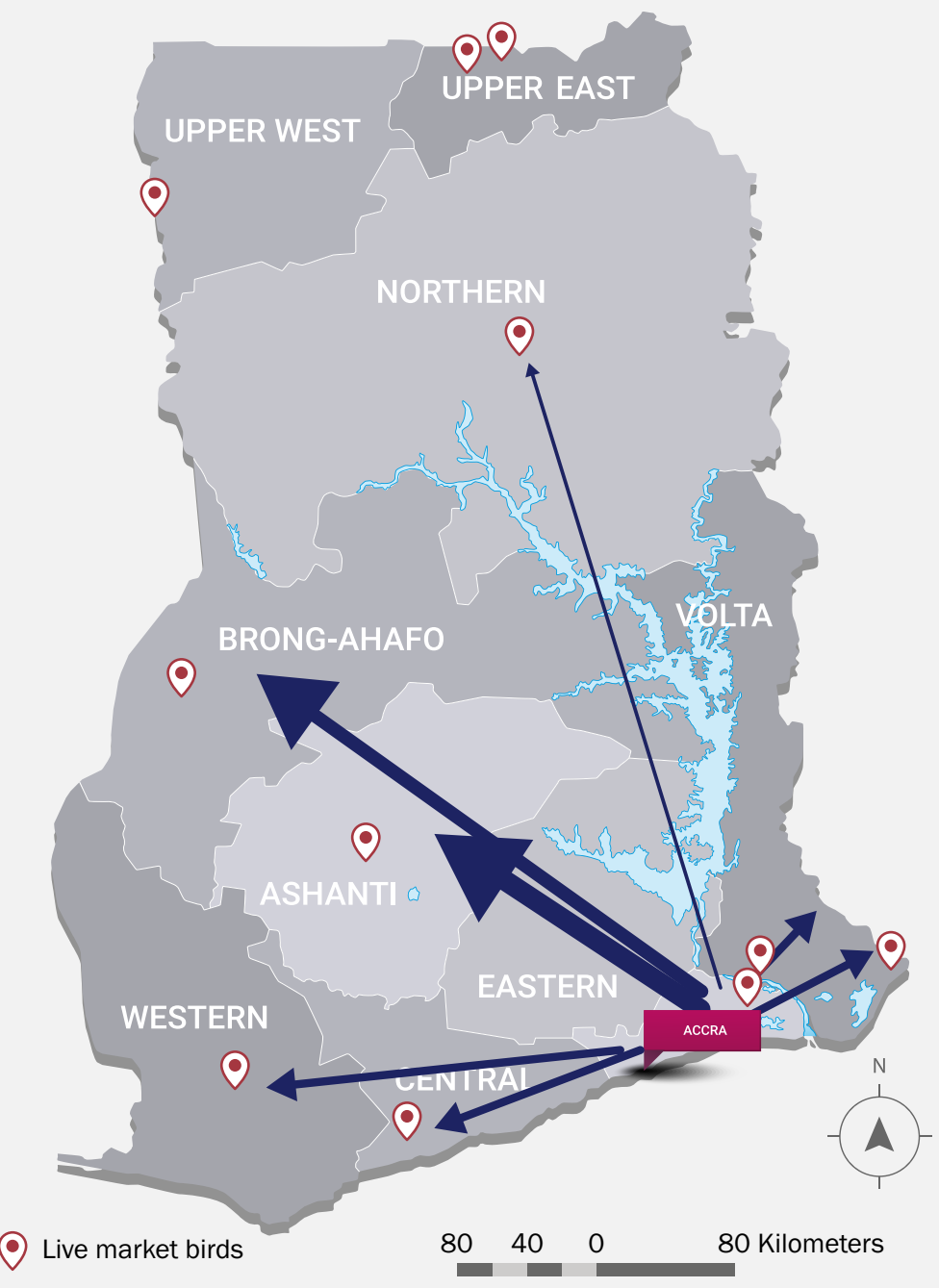

4.8 Mapping the value at different levels of the value chain

Mapping how value is added at each step of the value chain is important to understand how value changes through the different levels of the value chain (by analyzing costs and margins), so as to understand the earnings at the different stages of the value chain. Also, the strength and weaknesses of costs and margins in the value chain can be summarized. Then, the constraints and needs of the value chain can be identified and interventions can be suggested. Historic costs and margins can be used to find out what the financial trends have been in the value chain and if the chain has a potential for growth, while the actual costs and margins can be used to understand if the value chain is remunerative. Information regarding costs can be obtained from the literature as well as from the various actors. Understanding costs and margins allows to determine cost of entry and the distribution of costs and margins between the actors to understand if actors can increase their margins by making the chain

Table 9 cost categories

\begin{tabular}{|c|c|c|c|c|c|}
\hline \multicolumn{2}{|l|}{ Operating costs } & \multirow[t]{2}{*}{ Transaction costs } & \multicolumn{2}{|l|}{ Regulatory costs } & \multirow[t]{2}{*}{ Investments costs } \\
\hline Variable & Fixed & & Variable & Fixed & \\
\hline $\begin{array}{l}\text { : Inventory sold } \\
\text { Employees' } \\
\text { wages }\end{array}$ & 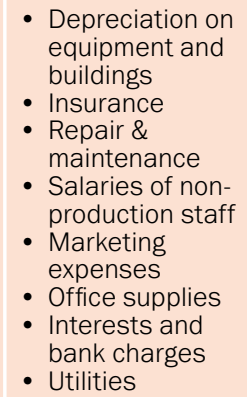 & $\begin{array}{l}\text { - Cost of obtaining } \\
\text { information for } \\
\text { traders e.g. } \\
\text { telephone calls, } \\
\text { - Legal conts of } \\
\text { contracts of }\end{array}$ & $\begin{array}{l}\text { - Licensing } \\
\text { External } \\
\text { grading e.g. } \\
\text { legally imposed } \\
\text { certificates } \\
\text { - Levies }\end{array}$ & - Internal grading & $\begin{array}{l}\text { - Principal } \\
\text { - Interest }\end{array}$ \\
\hline
\end{tabular}

Revenues can be calculated for each actor by multiplying the selling price (p) by the quantities sold (q) and adding to that other sources of more efficient (costs reduction) or effective (higher value). Moreover, it can be used for performance benchmarking by comparing the practices in these value chains with industry standards or best practices, to improve their effectiveness and efficiency.

When talking about costs, it is important to consider operating costs both fixed and variable and transactions costs, opportunity costs, regulatory costs, investment costs and cost of losses if the products are perishable (Table g). Variable costs are costs that change in direct relationship to the level of production, while fixed costs do not vary with the volume of production. For operating costs, the relevant costs types should be assigned to different activities performed by the same actor as this can help in identifying bottlenecks. Also, it is important to remember to consider that some of the costs can be shared between various products and therefore should be distributed between them.

income, for example revenues from selling production waste.

Revenues $=\left(q^{\star} p\right)+$ other sources of income 
When calculating revenues, it is important to consider that prices may differ across markets channels, market segments, per grade or

quantity and different seasons. Therefore, in such case the weighted average price should be used when calculating revenues. Financial ratios can also be calculated to determine the financial position of the actors. These include: Net income $=$ Revenues - Operating costs

Net margin $=\frac{(\text { Net income) }}{\text { (Quantity sold) }}$

Net Profit Margin $=\frac{\text { (Unit profit })}{\text { (Unit price) }}$

Break even point $=\frac{(\text { Fixed costs })}{(P-\text { Variable costs })}$

Return on investment $(R O I)=($ Net Income $)$ (Total Costs)

Costs and margins should be looked at over time to understand how they will be affected by variation in trends and to predict future growth or decline of the chain and thus the profitability over time. It may be interesting to compare the value chains in different regions, to understand the potential for efficiency gains by understanding the causes in variations if any.

\section{Example - Mapping of value}

Table 10 shows an example of how to calculate value added profits and margins along the value chain. This can help in determining the financial position of an actor compared to others. By analysing the data, it may appear for instance that farmers have high costs and low profits, while wholesalers have low costs and high profits. Thus, a good point of intervention may involve developing or scaling up the farmers business e.g. identifying alternative uses of biproducts so they can be sold by farmers to generate revenue.

Table 10 Small scale maize farmers production costs, sales and margins (Source: (M4P, 2008)

\begin{tabular}{|c|c|c|c|c|c|c|c|}
\hline \multirow[b]{2}{*}{ Actor } & \multicolumn{3}{|c|}{ Costs } & \multirow{2}{*}{$\begin{array}{l}\text { Revenues } \\
\text { Unit Price }\end{array}$} & \multicolumn{2}{|c|}{ Profits } & \multirow[t]{2}{*}{ Unit margins } \\
\hline & $\begin{array}{l}\text { Unit Total } \\
\text { cost }\end{array}$ & $\begin{array}{l}\text { Added Unit } \\
\text { Cost }\end{array}$ & $\begin{array}{c}\% \text { Added } \\
\text { Cost }\end{array}$ & & Unit profit & $\begin{array}{l}\text { \% Total } \\
\text { Profits }\end{array}$ & \\
\hline Farmers & A & & $A / F$ & G & G-A & $(G-A) /(K-F)$ & G \\
\hline Assemblers & G & B & $B / F$ & H & H-B-G & $(H-B-G) /(K-F)$ & $H-G$ \\
\hline Processors & $\mathrm{H}+\mathrm{C}$ & c & $C / F$ & 1 & I-C-H & $(I-C-H) /(K-F)$ & $\mathrm{I}-\mathrm{H}$ \\
\hline Wholesalers & I+D & D & $\mathrm{D} / \mathrm{F}$ & J & J-D-1 & $(J-D-D) /(K-F)$ & $J-1$ \\
\hline Retailers & $J+E$ & E & $E / F$ & k & K-E-J & $(K-E-J) /(K-F)$ & k-J \\
\hline Total & & $F=A+B+C+D+E$ & 100 & & $K-F$ & 100 & K \\
\hline
\end{tabular}

4.9 Mapping the relationships and linkages between the actors

This requires understanding and showing the relationships and linkages between the actors in different processes and within the same process and indicating them using different arrows, in order to understand the stability of supply and maintainability of quality which can be affected if purchases are conducted from different suppliers each time. This information can be obtained through interviews. Usually, there are 3 types of relationships existing between actors as seen in figure 8 .

Fisure 8 Types of relationships between actors

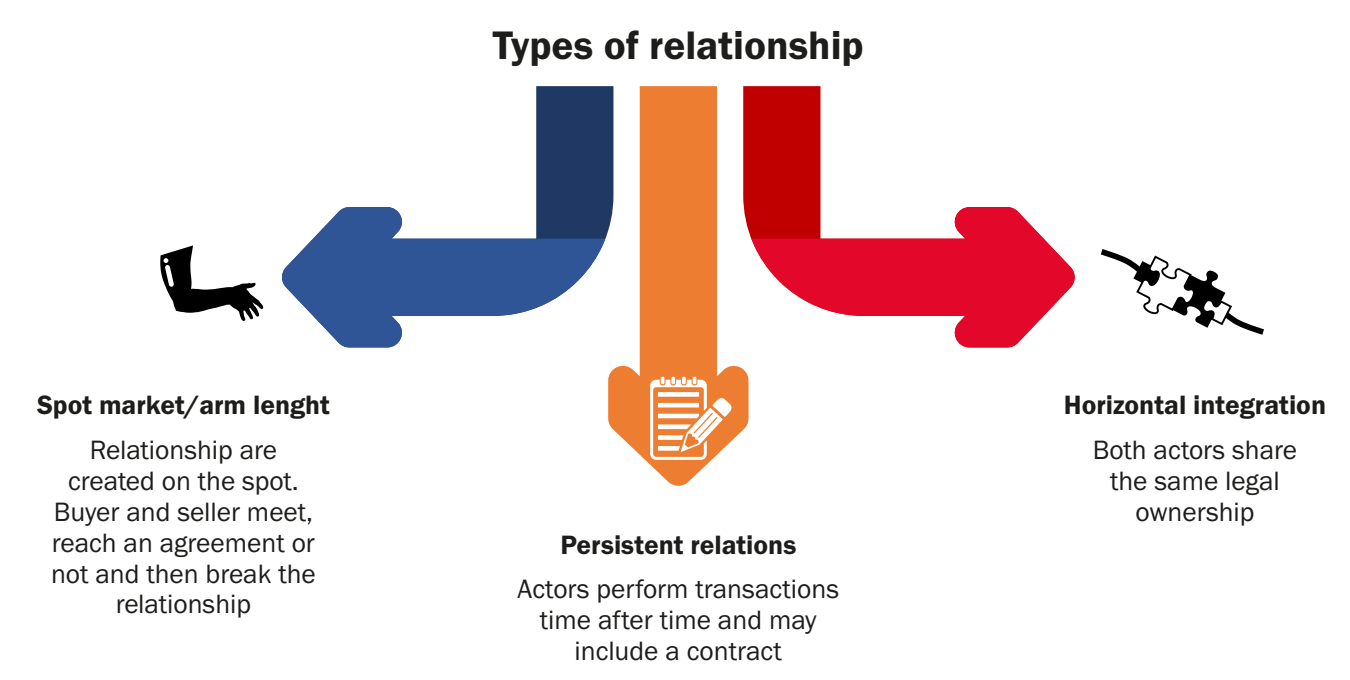

4.10 Mapping the services and governance in the value chain

This step implies mapping the services that are provided in the value chain, including the sources and payment procedures (embedded, fee based or subsidized). Services may be provided by actors outside or within the chain for instance when buyers help suppliers to achieve quality standards. By analysing the services it is possible to understand if the necessary services are provided, who provides them, to which of the actors are they provided are they sufficient and with the required quality and if they are capable of supporting improvements needed in the supply chain.

Mapping the rules and regulations that govern the supply chain is also important in order to have an overview of the potentials of intervention outside the value chains. The idea is to understand how the rules impact the various actors, who sets the rules and the reason behind them. Rules and regulations can be formal or informal, hence they are determined by commercial norms. Furthermore, standards required for exportation are usually more complex than those governing local and national markets. For simplification, governance and services can be broken down into rules, regulations and control mechanisms and collection of data for analysis should begin by generating a list of all the actors (internal or external to the value chain) that are capable of influencing the governance structure. This can be done based on the literature review an then completed through qualitative interviews with key actors. Information regarding governance and services can be gathered through semi-structured interviews and then, this can be summarized in a matrix that can be used for the analysis in the second round of interviews with the other actors, following a backward linkage in the chain if needed. Then, the impact of these rules and regulations on the value chain can be studied by identifyin the systems of sanctions available to detectors and incentives that reward the application of these rules. 
4.11 Mapping constrains and potential solutions

Another step is mapping all the identified

constrains and potential feasible solutions

that can be made in each process level. It

is important when providing solutions not to

Example - Mapping constrains and possible solutions

Table 11 shows an example of constrains identified for the poultry industry in Ghana, and the possible solutions to resolve them.

\section{Table 11 Chicken supply and production constraints and solutions}

\begin{tabular}{|c|c|c|c|}
\hline & Supply Inputs & Production & Processing \\
\hline Constrains & $\begin{array}{l}\text { - Lack of quality standards and regulations } \\
\text { - Ln feed. } \\
\text { Low quality of day-old chicks }\end{array}$ & $\begin{array}{l}\text { : High cost of production } \\
\text { Low biosecurity }\end{array}$ & $\begin{array}{l}\text { - Cheaper imported chicken } \\
\text { meat } \text { Limited processing capacity } \\
\text { compared to demand }\end{array}$ \\
\hline $\begin{array}{l}\text { Potential } \\
\text { solutions }\end{array}$ & $\begin{array}{l}\text { - Setting up a regulatory body that sets } \\
\text { clear standards, certifications, and trains } \\
\text { on feed production } \\
\text { Investment in new hatchery technologies } \\
\text { and equipment, and transfer of knowledge } \\
\text { regarding advanced techniques }\end{array}$ & $\begin{array}{l}\text { - Promote local production of } \\
\text { - Maize and soyat beans } \\
\text { Set tib-security regulations } \\
\text { and certifification }\end{array}$ & $\begin{array}{l}\text { : Set policy to limit imports } \\
\text { Introducuing new processing } \\
\text { facilities }\end{array}$ \\
\hline
\end{tabular}

\subsection{Developing a value chain map matrix}

The value chain map matrix summarizes

on which actors to interview, what information

$$
\text { (M4P, 2008) }
$$

jump into conclusions and choose an obvious be used to help in identifying the auses of problems.
Example - Value chain map matrix

Table 12 summarizes the poultry value chain, it is possible to include other data such as costs, margins,

\begin{tabular}{|c|c|c|c|c|c|c|}
\hline & Inputs & Activities & Outputs & Actors & Challenges & $\begin{array}{l}\text { Possible } \\
\text { solutions }\end{array}$ \\
\hline Input supply & & & $\begin{array}{l}\text { Day old chicks, } \\
\text { Feed and } \\
\text { additives, } \\
\text { Vaccination, } \\
\text { Drugs etc... }\end{array}$ & $\begin{array}{l}\text { Poultry director, } \\
\text { Feed millers, } \\
\text { Hatchery } \\
\text { manaerers, } \\
\text { Importers etc... }\end{array}$ & $\begin{array}{l}\text { - Lack of } \\
\text { quality } \\
\text { standards } \\
\text { and } \\
\text { regulations } \\
\text { - on feed. } \\
\text { Low quality of } \\
\text { day-old chicks }\end{array}$ & $\begin{array}{l}\text { - Setting up } \\
\text { a regulatory } \\
\text { body that } \\
\text { sets claer } \\
\text { standards, } \\
\text { certifications } \\
\text { and trains } \\
\text { on feed } \\
\text { production } \\
\text { - Investment in } \\
\text { new hatchery } \\
\text { technologies } \\
\text { and } \\
\text { equipment, } \\
\text { and transfer } \\
\text { of knowledge } \\
\text { regarding } \\
\text { advanced } \\
\text { techniques }\end{array}$ \\
\hline Production & $\begin{array}{l}\text { Day-old chicks, } \\
\text { Feed and } \\
\text { additives, } \\
\text { Vaccination, } \\
\text { Drugs etc... }\end{array}$ & $\begin{array}{l}\text { Health } \\
\text { monitoring, } \\
\text { Feeding and } \\
\text { watering, } \\
\text { Collecting, } \\
\text { sorting and } \\
\text { packing enggs } \\
\text { etc... }\end{array}$ & $\begin{array}{l}\text { Live chicken, } \\
\text { Egg crates etc.. }\end{array}$ & $\begin{array}{l}\text { Farmers, Co- } \\
\text { operatives, } \\
\text { Associations }\end{array}$ & $\begin{array}{l}\text { - High cost of } \\
\text { production } \\
\text { Low } \\
\text { biosecourity }\end{array}$ & $\begin{array}{l}\text { - Promote local } \\
\text { production } \\
\text { of maize and } \\
\text { soya beans } \\
\text { - Set bio- } \\
\text { security } \\
\text { regulations } \\
\text { and } \\
\text { certification }\end{array}$ \\
\hline Processing & $\begin{array}{l}\text { Live chicken, } \\
\text { Egg crates etc... }\end{array}$ & $\begin{array}{l}\text { Slaughtering, } \\
\text { Packing, } \\
\text { Refrigerating, } \\
\text { Transporting } \\
\text { etc... }\end{array}$ & $\begin{array}{l}\text { Whole dressed } \\
\text { chicken, } \\
\text { Pre-cuts, } \\
\text { Frankfurters, } \\
\text { Sausages, } \\
\text { Nuggets, etc... }\end{array}$ & $\begin{array}{l}\text { Food processing } \\
\text { companies, } \\
\text { Farmers, } \\
\text { Associations }\end{array}$ & $\begin{array}{l}\text { - Cheaper } \\
\text { imported } \\
\text { chicken meat } \\
\text { - Limited meat } \\
\text { processing } \\
\text { capacity } \\
\text { compared to } \\
\text { demand }\end{array}$ & $\begin{array}{l}\text { - Set policy to } \\
\text { limit imports } \\
\text { - Introducing } \\
\text { new } \\
\text { processing } \\
\text { facilities }\end{array}$ \\
\hline Wholesaling & $\begin{array}{l}\text { - Whole } \\
\text { dressed } \\
\text { chicken, } \\
\text { Frankfurters, } \\
\text { Sausages, } \\
\text { Egg crates, } \\
\text { Live birds, } \\
\text { Precuts, Eggs } \\
\text { crates, } \\
\text { Imported/ } \\
\text { local pre-cuts } \\
\text { etc... }\end{array}$ & $\begin{array}{l}\text { Transporting, } \\
\text { Cold storagege, } \\
\text { Selling to final } \\
\text { consumer etc... }\end{array}$ & $\begin{array}{l}\text { Whole dressed } \\
\text { chicken, } \\
\text { Frankfurters, } \\
\text { Sausages, Egg } \\
\text { crates, Live } \\
\text { birds, Pre-cuts, } \\
\text { Eggs crates, } \\
\text { Imported/local } \\
\text { pre-cuts etc... }\end{array}$ & $\begin{array}{l}\text { Wholesalers, } \\
\text { Importers, } \\
\text { Leaders }\end{array}$ & & \\
\hline Retailing & $\begin{array}{l}\text { Live birds, } \\
\text { Whole dressed } \\
\text { chicke, } \\
\text { Imported/ local } \\
\text { pre-cuts etc... }\end{array}$ & $\begin{array}{l}\text { Primary } \\
\text { processing, } \\
\text { Cold storage, } \\
\text { Sellining to final } \\
\text { consumer etc... }\end{array}$ & $\begin{array}{l}\text { Live birds, } \\
\text { Whole dressed } \\
\text { chicken, } \\
\text { Imported/ local } \\
\text { pre-cuts etc... } \\
\text { Retailers, Road } \\
\text { side shops }\end{array}$ & & & \\
\hline Consumption & $\begin{array}{l}\text { Live birds, } \\
\text { Pre-cuts, } \\
\text { Frankfurters, } \\
\text { Sausages, Eggs, } \\
\text { Boiled eggs, } \\
\text { Imported/local } \\
\text { pre-cuts etc... }\end{array}$ & & $\begin{array}{l}\text { Households, } \\
\text { Restaurants, } \\
\text { Chop bars etc... }\end{array}$ & & & \\
\hline
\end{tabular}
locations, and quantities. 


\section{Process mapping}

\section{Objectives}

- Identify bottlenecks, inefficiencies, repetitions, and delays

- Provide insight into a process

- Assist in process improvement

- To show relationship between activities

- Enhance problem solving

Process mapping can also be used in conjunction with value stream mapping for identification of bottlenecks and to provide in depth understanding of specific processes along the supply chain, if necessary. Moreover, it allows to identify unnecessary, inefficient, or duplicated activities in a process. Developmen of the process map would require observing

the processes and conducting semi-structured interviews with those involved in the processes (those who do and manage the process and provide the inputs). Below are the steps to develop a process map

1 Identify the process to map

2 Gather the following information

- The activities that are performed in the process

- The events or decision points in the process

- The inputs and outputs of each activity - Who does what? When, where and how? Before documenting the as-is process it is necessary to have a clear understanding of the process and this can be done through one of the following manners:
- Observing the process as it is going

- Conducting interviews with employees of

different roles working in the process

- Conducting surveys on the process

3 Organize the steps in sequential order

4 Draw the as-is process map. This is the documentation of the process as it is

being performed currently. The most straightforward way to do this is with a process flowchart.

5 Analyse the map to identify insufficiencies, flaws, and bottlenecks within the processes, what are the steps that should be eliminated and where can improvements be made. There is no straight forward way to do this however asking the following questions can help: are some steps in the process taking unusually long, time or money sinks and why? Are some process steps generating losses or are unnecessary? Which step have the highest impact on output and are there ways to make it more efficient? Can this step be automated using technology (TallyFly, 2020)?

6 Draw the to-be process map. This is similar to the as-is process map, however it shows how the process should be adjusted according to the findings from step 5.

7 Implement the improvements (Athuraliya, 2019)
Example - As-Is process map

Figure 9 shows an example of the as-is process map for an on-farm feed mill. The current process involves cleaning grains (removing foreign bodies) in a machine and then packing them and then moving the raw materials to another machine that mills and mix them, after which the produced feed is packed. This causes the process to be inefficient and increases the labour work and costs. By purchasing clean grains or investing in a mill that includes an internal cleaning step it is possible to save on the feed production time and to utilize the labour to work on the other activities of the farm.

\section{Figure 9 Feed mill process map}

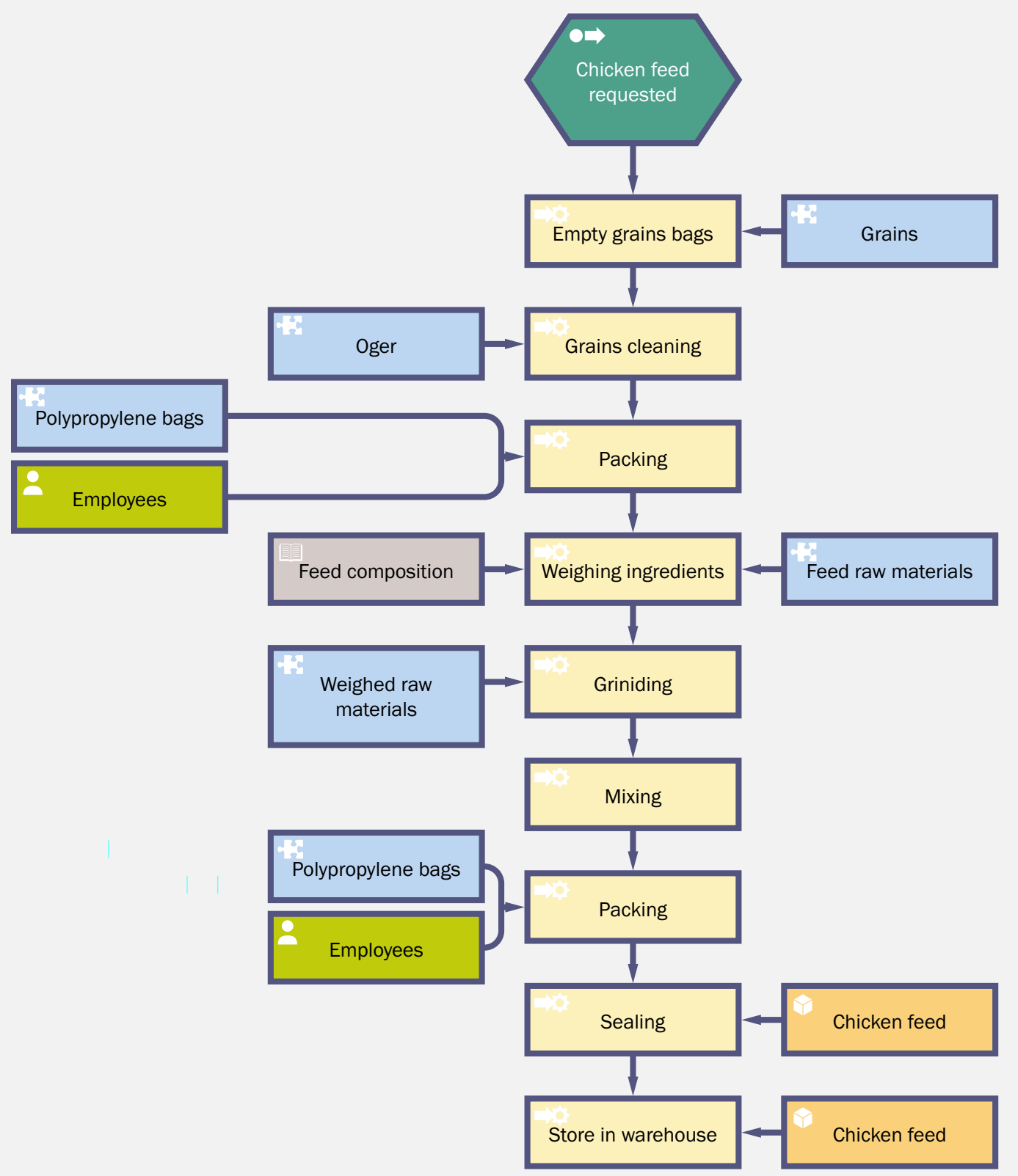




\section{Finding the cause of the problem}

\section{Objectives}

- Discovering the root cause of a problem

- Understanding how to fix or learn from issues within the root cause

- Applying what is learnt from the analysis to prevent future issues

It is important when tackling problems not to jump into conclusions but to deeply think about the problem, understand it better in order to identify its deeper cause and not to concentrate on the immediate problems that arise. When tackling a problem it is good to consider inputs from those who are facing the problem, particularly those operating in the field, this is because in many cases people

follow specific routines although they may know the solution to the problem, they may not think about solving it. Moreover, a good step following the identification of problems is to rank the problems and solutions in terms of impact, ease of solving and feasibility. This is because many problems may appear, and it may not be possible to solve them at the same time. In addition, it may be that some of the problems are linked together and thereby solving one problem may ultimately cause others to disappear. The below steps can be followed to identify and fix problems:

1) Background definition - This involves defining the problem in a clearer sense by answering to the following questions:

- What is the problem that is being faced? Why the problem is relevant (how is the problem related to the stakeholders

they usually lead to physical problems

c Organizational causes: a process, system or policy that is used by people to make

decisions or to perform their work is

faulty

or to the product itself)? Why are we talking about the problem? Who is interested in solving this problem? What are the benefits of solving this particular problem and can this help in resolving other issues that the problem may be connected to and what are they?

2) Current situation - After the problem is defined, it is important to capture and analyse the current state of the situation. This can be done by observing the working processes and documenting them. If

possible, it would be useful to also quantify the size of the problem.

3) Root cause analysis (RCA) - This involves looking deeper into the problem in order to define the actual cause/s of the problem. The idea is not to look at the symptoms, what appears on the surface, but rather to look deeper and understand what is causing the problem and fixing the processes and systems so the problem does not appear again. Root cause analysis involves identifying the origin of the problem so as the determine: what happened? why it happened? And to determine what to do to reduce the likelihood that it may occur again. Normally, the causes of the problem can be divided into three types:

a Physical causes: such as failure of tangible materials

b Human causes: things that were done wrong or were not done by people, and
The process for RCA involves four step that are explained below:

a Problem definition: what is happening and what are the specific symptoms.

b Data collection: how long has the problem existed? What is the impact of the problem? And what are the proofs that it exists?

c What are the possible factors: what sequence of events and conditions allow the problem to happen? What other problems surround the occurrence of the problem? Several tools can be used to identify the factors that lead to the problem. These

include:

- Interviews

- 5 Whys? - This technique is a more in-depth problem-solving tool. It involves the description of the problem to be addressed and then working backward asking why the problem occurred. You should keep asking "why?" in each step until the root cause of the problem is reached (Figure 10). By continuously asking why, one is capable of removing the symptoms that lead to the root cause of the problem. Although it is called 5 whys it is possible to ask fewer or more times until the issue related to the problem is determined.

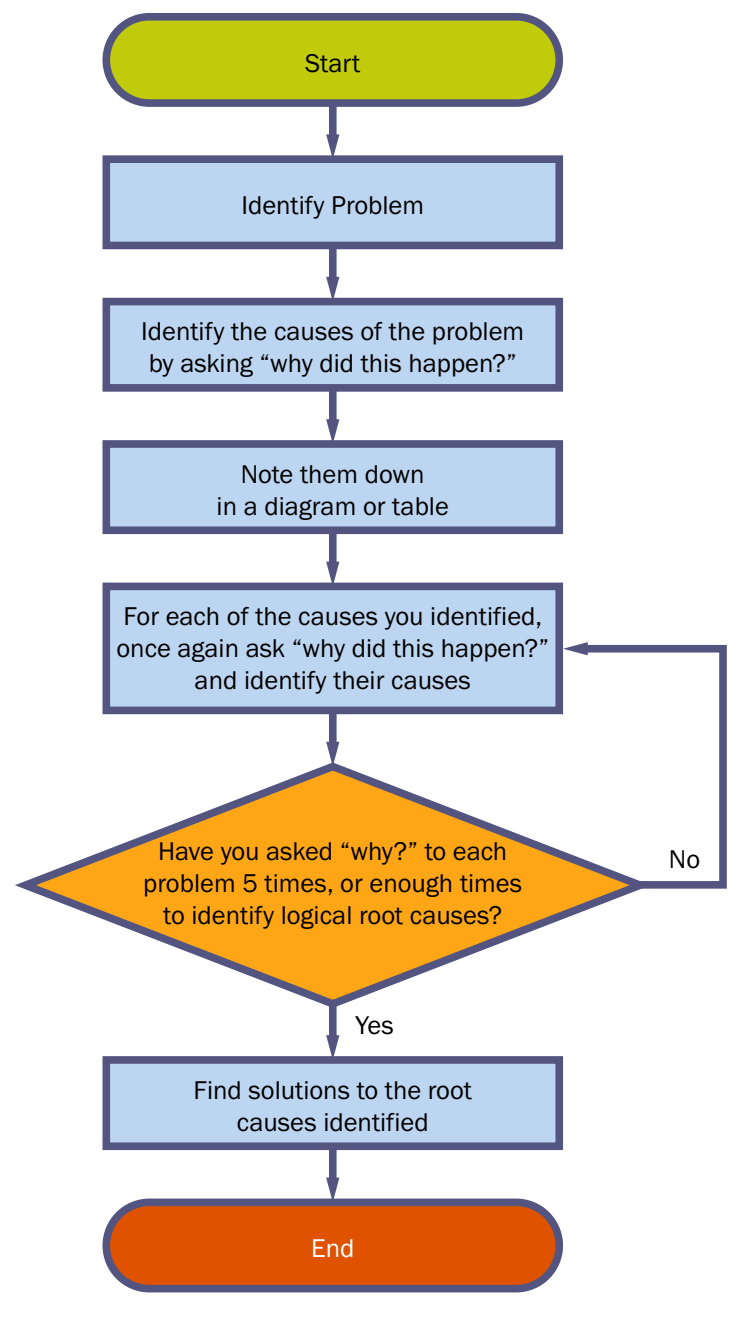

Figure 10 5-Whys process flowchart (Source: (Seiter, 2018)

- Cause and effect / ishikawa / fishbone diagram - This system examines why something happened or may happen by organizing potential causes into smaller categories. Also, it can be used to understand the relationship between contributing factors. To make the cause and effect diagram, first identify the problem statement (effect) and write it down as shown in the Figure 11. After that, draw a horizontal line from the written problem and identify the major categories of causes for the problem and write them as branches as shown in the Figure 11. A generic heading of 
categories that can be used is referred to as $6 \mathrm{M}$ 's which includes:

Machines (equipment): are there

problems with the equipment used

or maintenance issues with the tools

used? Or is there an issue regarding

the availability or insufficiency of tools/

machines?

Man: is there too little workforce devoted

o a process? Are new people adequately

trained? Is the training consistent? Are

the right people with the right experience

eing hired or promoted? Is there a

specific position creating a bottleneck or

making frequent mistakes?

Methods: are there well-written and

appropriate training guidelines in place?

Are certain policies or regulations causing slow-downs or creating unnecessary

steps?

Materials: are there issues with getting raw materials from suppliers? Are there problems with transportation (timing) or with the quality of the supplies obtained? Measurements: could there be errors in calculation or contamination that caused false readings? Could the measurement methods be inconsistent in some way? Is equipment regularly calibrated and maintained?

Mother nature (environment): is there too much moisture in the environment? Are temperatures too hot or too cold? Is there excessive dust or other contamination? Are there problems regarding the environment where people operate?
After that, for each category of causes it is important to understand why they happen, identify the sub-causes and write them down as sub-branches, and keep digging deeper into causes. Once the diagram is complete, analyze the information as it has been organized in order to come to a solution and create action items. Figure 11 shows an example of a fish bone diagram.

d Identify the root cause/s: from the previous step determine why those factors exist and the actual reasons that cause the problems o occur(Mind To+19).

4) Develop countermeasures: these are ideas for tackling the situation. List as many countermeasures as possible and identify the countermeasure that directly addresses the root cause. Then determine how the solution can be implemented and if there are any risks involved. Once done with that, the obvious next step would be develop an action plan while including those involved, in order to buy them into mplementing the solution.

5) Implementation: this is the actual implementation of the solution/s. Usually there should be follow ups and measurements to ensure that the solution/s mplemented are providing the desired results.

\section{Example - Ishikawa}

Figure 11 Poultry Ishikawa

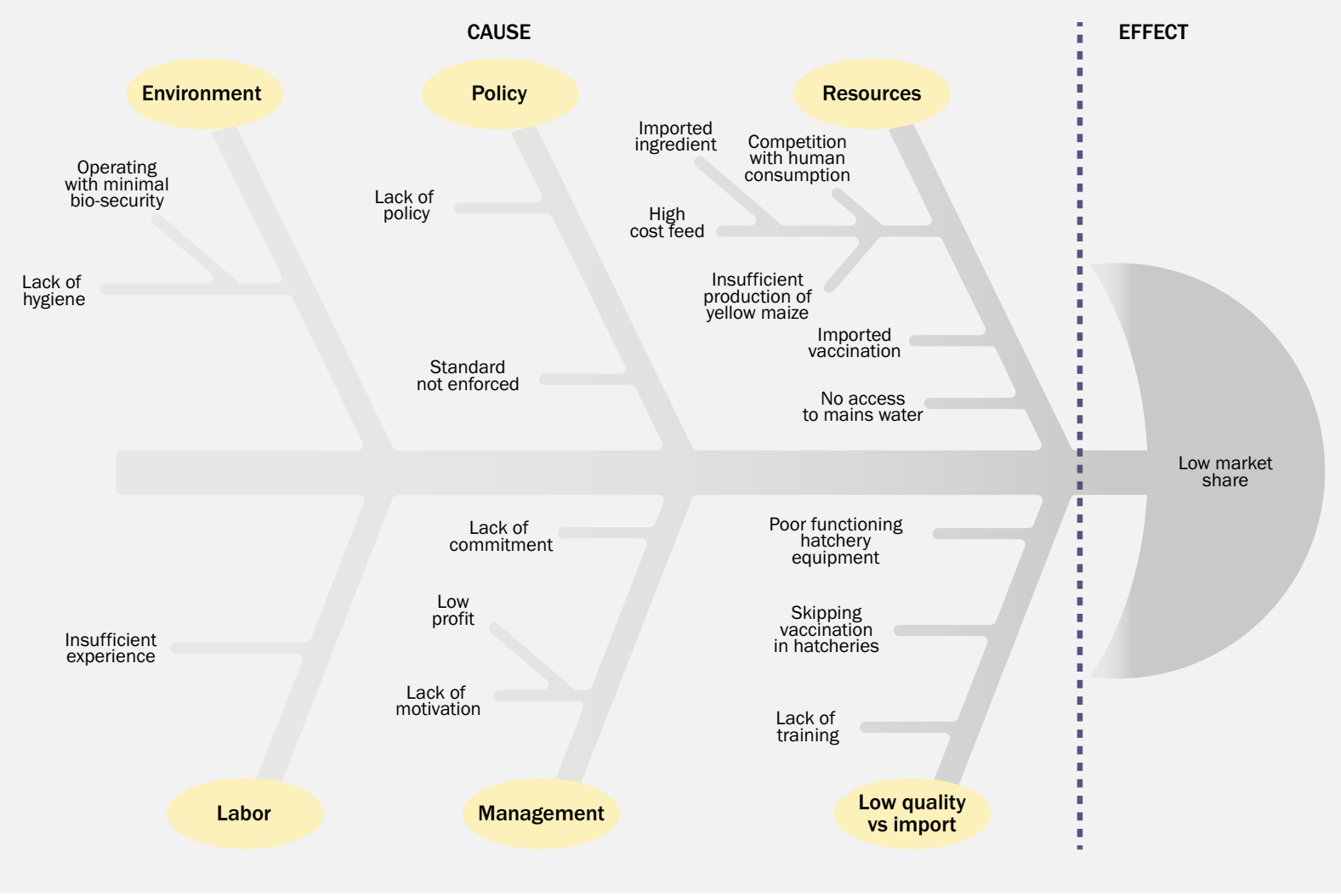




\section{SWOT}

\section{Objectives}

- Differentiating between strengths, weaknesses, opportunities, and threats

- Developing actionable strategies

SWOT is particularly helpful in identifying areas for development by assessing the Strength, Weaknesses, Opportunities and Threats. It is an analytical technique that provides answers to the questions related to each of the four words whose first letter forms the acronym. Strengths relates to the advantages, areas of excellence, relevant resources possessed and available institutions. Weaknesses refers to things to improve and areas of poor performance. Opportunities are the available enabling factors, favourable trends, and comparative advantages. Threats refers to the obstacles that interfere with and hinder success, and areas to avoid. Analysing the various industries according to SWOT analysis is equal to analysing the opportunities and threats that exist in the external environment, as well strength and weaknesses existing in the internal environment. Carrying out an analysis using the SWOT framework helps to focus

activities into areas of strengths and where the greatest opportunities lie.
Figure 12 Tows matrix (Source: (Mind Tools, 2020)

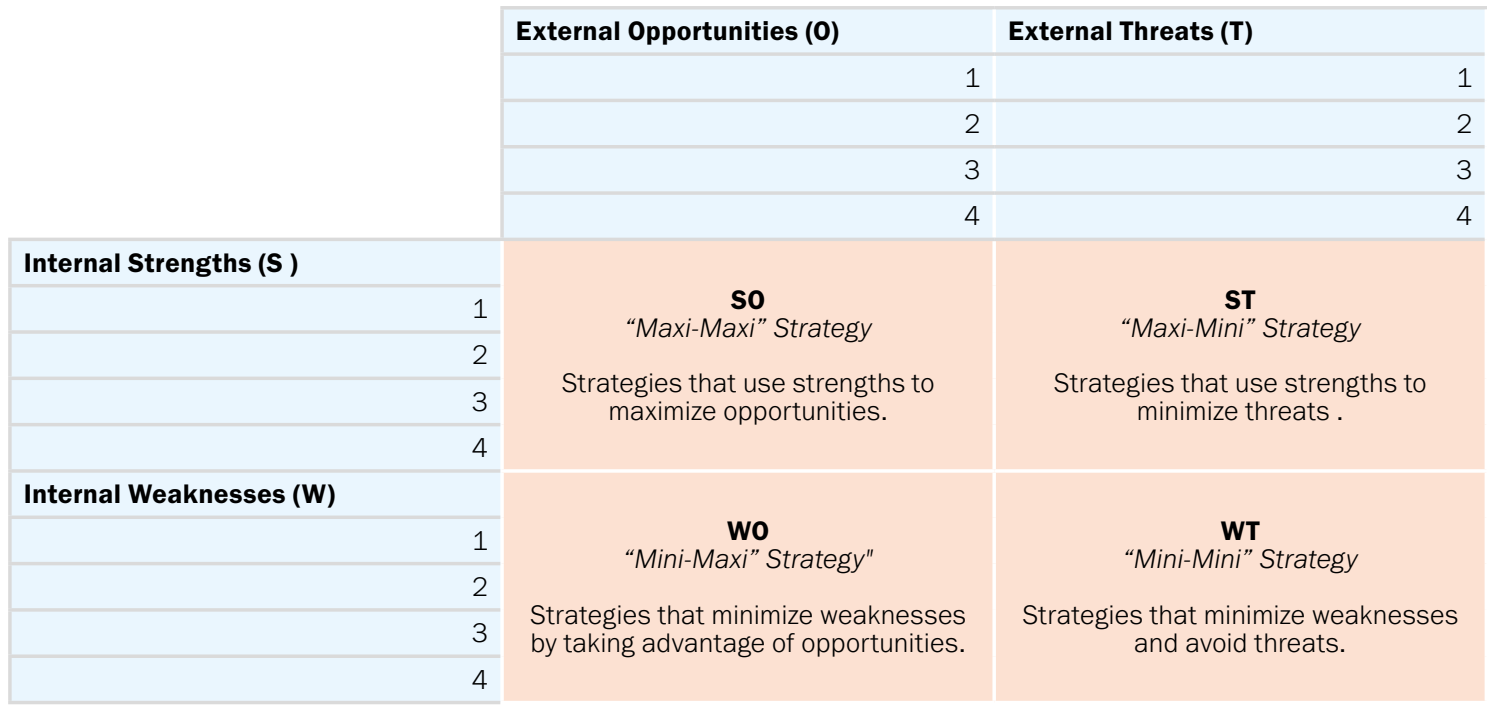

\section{Example - SWot Analysis}

Figure 13 shows an example of a strength, weakness, opportunity, and threat that was identified for the poultry industry based on the findings from the previous tools.

Figure 13 Poultry SWOT Analysis

opportunities be used to overcome weaknesses?

- Weakness and Threats (WT) - How can weaknesses be minimized to avoid threats. Figure 12 shows TOWS matrix where in the outside boxes the identified Strengths, Weaknesses, Opportunities and Threats are included and then matched in the internal boxes.

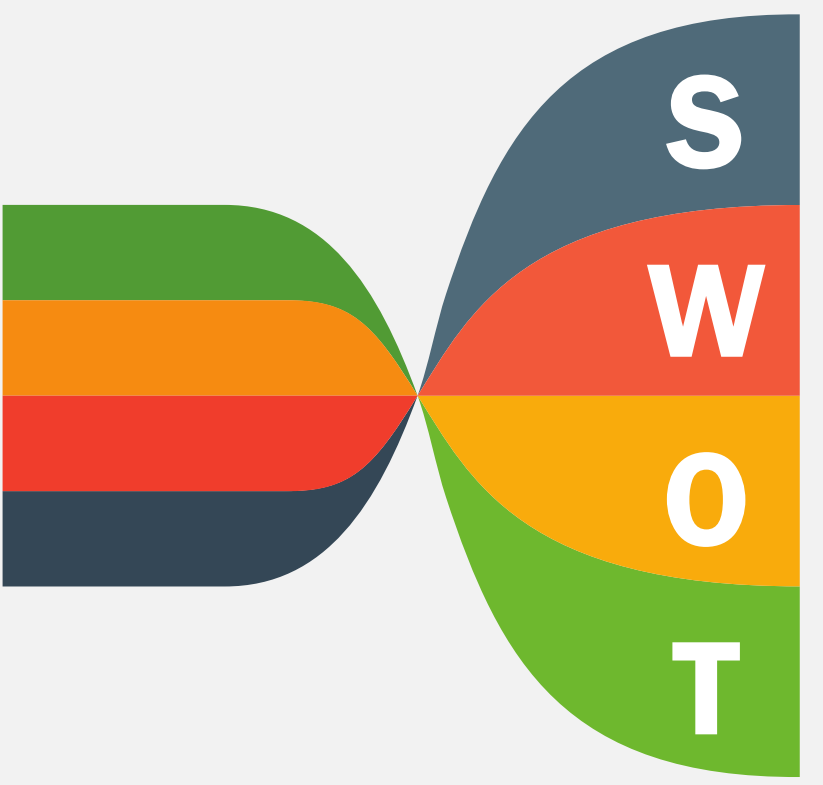

STRENGHT

Increasing demand for poultry products

\section{WEAKNESS}

High input costs

\section{OPPORTUNITY}

Local production of vaccinations

THREAT

Decline in chicken meat production 


\section{References}

Akunzule, A. N. (2004). Livestock Country Reviews. Poultry Sector Ghana. FAO Animal Production an Health Livestock Country Reviews. No. 6. Rome. https://doi.org/10.1029/2011JD017016

Athuraliya, A. (2019). The Easy Guide to Process Mapping. Retrieved from https://creately.com/blog/ diagrams/process-mapping-guide/

\section{Fourcadet, 0., \& Attaie, H. (2003). GUIDELINES}

FOR VALUE CHAIN ANALYSIS IN THE AGRI-FOOD

SECTOR OF TRANSITIONAL AND DEVELOPING

ECOMONIES ESSEC Business School France, MBA

in international Agri-Food Management. Hila Attaie

\& GUIDELINES FOR VALUE CHAIN ANALYSIS IN THE

AGRI-FOOD SECTOR OF TRAN, (December).

\section{Galal, N. M., \& Moneim, A. F. A. (2016).}

Developing Sustainable Supply Chains in Developing

Countries. Procedia CIRP, 48, 419-424. https://doi.

org/10.1016/j.procir.2016.03.156

Grossi, M. (2014). Supply chain analysis. Retrieved from http://www.coastalwiki.org/wiki/Supply_chain_ analysis

Happek, S. (2005). Supply Chain Strategy - The Importance of Aligning Your Strategies. Solutions,

1-7. Retrieved from ups-scs.com

Kaplinsky, R., \& Morris, M. (2000). A HANDBOOK FOR VALUE CHAIN An Important Health Warning or Guide for Using this Handbook, (September).

L., H., \& Lee. (2002). Aligining supply chain strategies with product uncertainities.
M4P. (2008). Making Value Chains Work Better for the Poor: A Toolkit for Practioners of Value Chain Analysis, Version 3, Making Markets Work Better for the Poor (M4P) Project, UK Department for International Development(DFID). Agricultural Development International : Agricultura

Development International: Phnom Penh Cambodia.

MBA Skool. (2008). End of Season Markdowns.

Retrieved from https://www.mbaskool.com/

business-concepts/marketing-and-strategy-

terms/10960-end-of-season-markdowns.htm

Miemczyk, T. E. J. M. H. J. (2014). Purchasing \&

Supply Chain Management.

Mind Tools. (2019). Root Cause Analysis. Retrieved from https://www.mindtools.com/pages/article/

newTMC_80.htm

\section{Mind Tools. (2020). TOWS Matrix. Retrieved}

from https://www.mindtools.com/pages/article/

newSTR_89.htm

Seiter, C. (2018). The 5 Whys Process We Use to

Understand the Root of Any Problem. Retrieved from

https://open.buffer.com/5-whys-process/

TallyFly. (2020). How to do Process Improvement with As-Is and To-Be Processes. Retrieved from https://tallyfy.com/as-is-to-be-business-process/

The Supply Chain Consulting Group. (2020)

Lean vs Agile Supply Chains. Retrieved from https:// www.sccgltd.com/archive/lean-vs-agile-supplychains-part-1/
United States Department of Agriculture. (2014). Inspection \& Grading of Meat and Poultry: What Are the Differences? Retrieved from https://www.fsis.usda.gov/wps/portal/fsis/ topics/food-safety-education/get-answers/foodsafety-fact-sheets/production-and-inspection inspection-and-grading-of-meat-and-poultry-whatare-the-differences_/inspection-and-gradingdifferences/!ut/p/a1/jZFRT4MwE

\section{Vincent Amanor-Boadu, F. K. N. and K. R.}

(2016). Structure of Ghana 's Chicken Industry in 


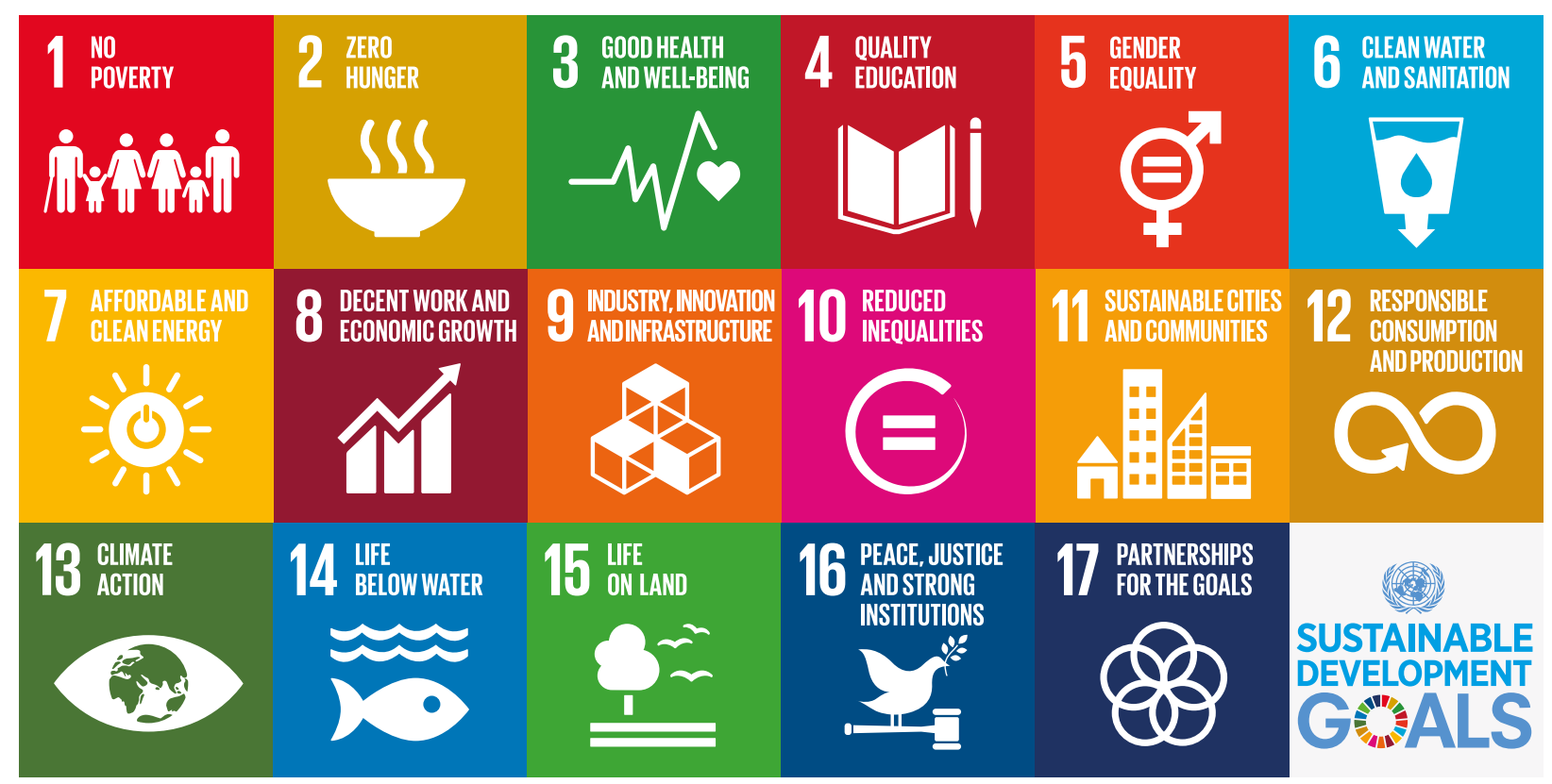

The Fondazione Eni Enrico Mattei (FEEM), founded in 1989, is a non profit, policy-oriented, international research center and a think-tank producing high-quality, innovative, interdisciplinary and scientifically sound research on sustainable development. It contributes to the quality of decision-making in public and private spheres through analytical studies, policy advice, scientific dissemination and high-level education. Thanks to its international network, FEEM integrates its research and dissemination activities with those of the best academic institutions and think tanks around the world.

\section{Fondazione Eni Enrico Mattei}

Corso Magenta 63, Milano - Italia

Tel. +3902.520 .36934$

Fax. +39.02.520.36946

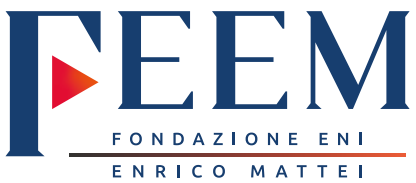

E-mail: letter@feem.it 